\title{
Evolution of the Driftless Area and Contiguous Regions of Midwestern USA Through Pleistocene Periglacial Processes
}

\author{
Michael Iannicelli, ${ }^{*}$
}

142976 Street, Brooklyn, New York, NY 11228, USA

\begin{abstract}
In the Driftless Area region and contiguous regions (Paleozoic Plateau and Iowan Erosion Surface) within the U.S.A., there are a variety of northwest to southeast oriented landforms. They are interpreted to have been formed by periglacial nival and cryoplanation erosion processes during the Pleistocene. It is proposed that the oriented landforms are initiated by erosion focused along the edges of northwest-southeast trending snow dunes. Over time, cryopedimentation/cryoplanation widens some of the landforms into broad pediments or planed surfaces. These processes left other landforms standing as narrow, northwest-southeast trending, isolated ridges (paha and rock paha). Oriented valleys were carved in bedrock in some areas and were also carved in loess or loess underlain by till within other areas. An overall regional northeast to southwest trend of increasing amounts of pre-Illinoian till cover is interpreted to form by different degrees of widespread nival erosion. The Pleistocene wind was an important, indirect cofactor in the development of both the till pattern and the previously mentioned landforms. Determining these events not only helps us to formulate an evolutionary model for all three regions as a unit but also justifies speculation that the Driftless Area may have been glaciated during pre-Illinoian times.
\end{abstract}

Keywords: Driftless area, snow dunes, rock paha, cryopedimentation, cryoplanation.

\section{INTRODUCTION}

\subsection{Location and Relevant Erosional Features}

The Driftless Area is a region that has an absence of till and erratics even though it is surrounded by territories having such material [1]. The west-central and southwestern parts of Wisconsin, extreme northwestern Illinois, and small portions of northeastern Iowa and southeastern Minnesota constitute this region [2, 3] (Fig. 1). The areas of northeastern Iowa and of southeastern Minnesota are part of the Paleozoic Plateau region that is mostly "driftless" with a few widely scattered patches of pre-Illinoian till [2] (Fig. 1). The till-covered Iowan Erosion Surface region is mainly located in northeastern Iowa and a smaller extension of it continues into Minnesota [4] (Fig. 1). The regions have similar erosional features formed during the Pleistocene such as: the stripping of most of the red clay residuum [2, 5]; truncated paleosols [2, 6, 7]; leveled summits and subsummits [8] plus an upland plain with hillside terraces [2, 9]; the existence of relict colluvium $[2,5,10]$ and a stone-line $[2,5]$. Peculiar and ubiquitous landforms in all three regions are NW-SE oriented, isolated, oblong to elongated hills on the previously-noted flat surfaces [11-13], and NW-SE oriented, contiguous valleys $[14,15]$.

The aim of this study is two-fold: to decipher the origin of particular, large-scale hierarchical, geomorphological units within the Driftless Area and the Paleozoic Plateau by correlating them to landforms both on the Iowan Erosion Surface and in northwestern Illinois just outside of the Driftless Area; and to provide an alternative explanation

*Address correspondence to this author at the 142976 Street, Brooklyn, New York, NY 11228, USA; Tel: 908-578-9456;

E-mail: michiann@optonline.net;

"Independent Researcher. about why the Driftless Area is "driftless". These objectives will try to be achieved in this study by uniting many established facts from different, credible sources into a synthesis. Qualitative and some quantitative data were compiled from peer-reviewed journals and material originating from governmental geological surveys such as geologic reports, field guidebooks, geologic logs and well construction reports. This generated novel insight (besides a background) about the geomorphology of the discussed regions. Reconnaissance of aerial photographs and many general bedrock, glacial, surficial geologic and topographical maps helped to correlate geomorphic units and erosional trends. There is no revelation in measuring the study areas' weathering and erosional rates because the landforms are relict. The aforementioned research is applied to the study's central thesis that is developed within the context of both the direct effects of (paleo)snow and the indirect effects of an anticyclonic wind system hovering over the Laurentide continental ice sheet. Both these influences advance the question of what other impressive manifestations arise from the infinite amount of Pleistocene snowfall besides it giving birth to the ruling, massive continental ice sheets. The present study seeks to tackle this question.

1.2. The Snowmelt Erosion-Oriented Forms-Planation Hypothesis for the Evolution of All Three Regional Landscapes

While others have discussed that small-scale constructional landforms such as blockslopes and other hillside deposits in the Driftless Area were created by Pleistocene solifluction and sheetwash under permafrost conditions [16, 17], they did not account for the larger-scale landforms that dominate the landscape today. It has also 


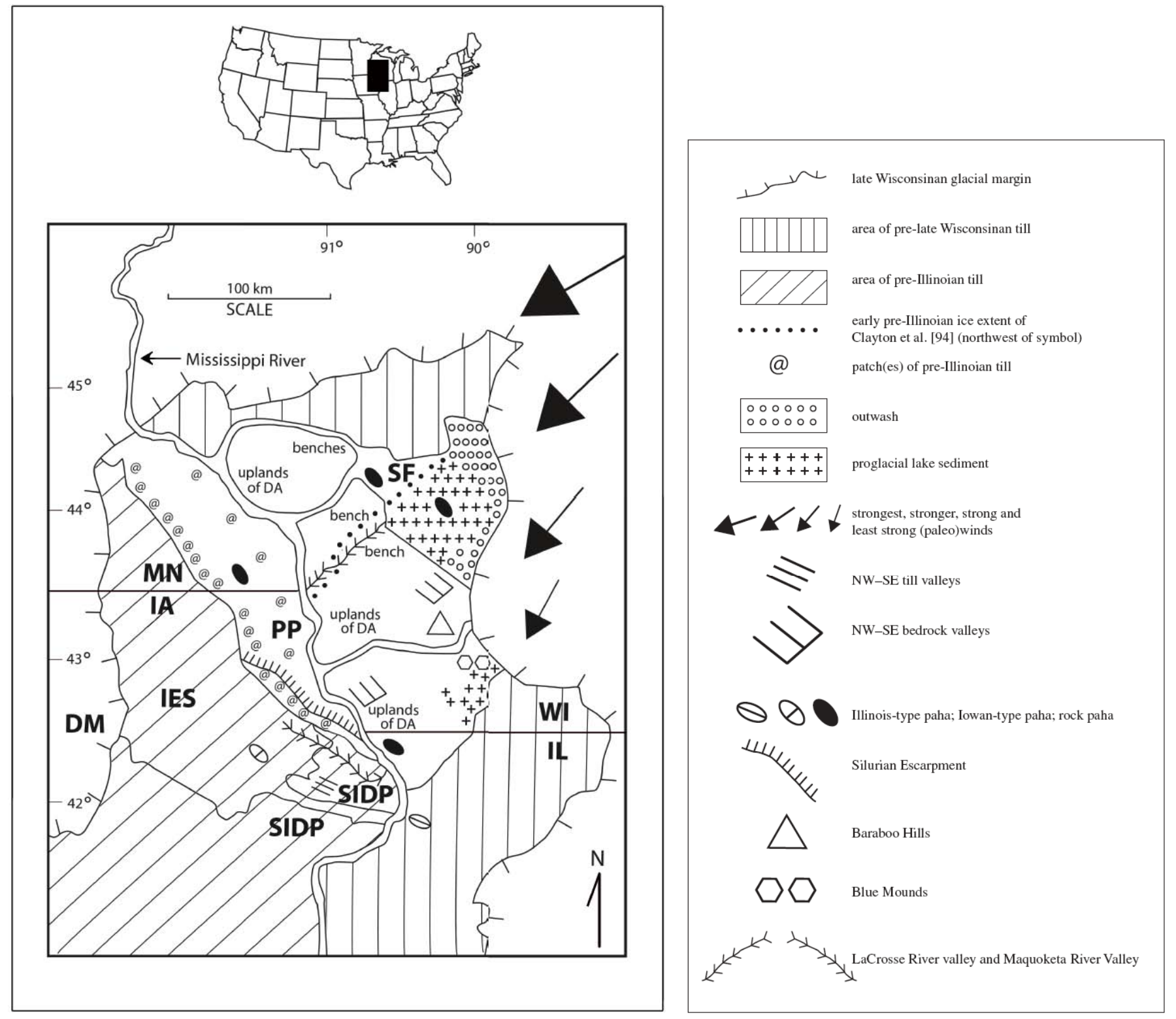

Fig. (1). Landforms map of the Driftless Area and adjacent regions. The landform symbols are not necessarily drawn to scale. DA = Driftless Area; PP = Paleozoic Plateau; IES = Iowan Erosion Surface; SF = sand flats within the Driftless Area; SIDP = Southern Iowa Drift Plain; $\mathrm{DM}=$ Des Moine Lobe of the late Wisconsinan Laurentide ice sheet which partially overprints the Pleistocene-age I.E.S.; WI = Wisconsin; IA = Iowa; IL = Illinois; MN = Minnesota. Vectors of different wind intensity and direction are also shown. Data from: Frankie and Nelson [3]; Wayne and Guthrie [4]; Prior [7]; Wiggers [8]; Hobbs and Goebel [10]; Brown [12]; Mossler [13]; Judson and Andrews [14]; Iannicelli [19, 20]; Clayton [22]; Horick [23]; Alden and Leighton [37]; Flemel et al. [51]; Black [62]; Mossler and Hobbs [77]; Hobbs [78]; Clayton et al. [94]; Thwaites [103].

been noted that large amounts of materials were stripped from the surfaces of the Paleozoic Plateau and the Iowan Erosion Surface during the Pleistocene by periglacial processes [18]. Iannicelli [19, 20] has developed the hypothesis that many unlithified, linear, NW-SE oriented landforms in the Midwest are the result of snowmelt erosion initiated and perpetuated along the edges of snow dunes. The present study will apply this concept to lithified (bedrock) landforms within the Paleozoic Plateau and the Driftless Area. It will be further hypothesized that larger-scale Pleistocene landforms in all three regions were formed by blankets of snow. This mode of snow promoted snowmeltsolifluction-sheetwash processes that produced local to regional cryopedimentation/cryoplanation surfaces. Another facet of the hypothesis proposes that the collective three regions are components of a single anomaly. An overall evolutionary model is devised while till patterns (Fig. 1) are rationalized here based on the hypothesis. This will ultimately forge a re-evaluation of certain pre-Illinoian glacial aspects (Figs. 1, 2) in this study.

\section{GEOLOGIC OVERVIEW}

The surficial bedrock of the Driftless Area is composed of mostly Paleozoic dolomite, limestone, sandstone and shale, along with a very small percentage of quartzite [21] (Table 1). The bedding is horizontal in the eastern half of the 

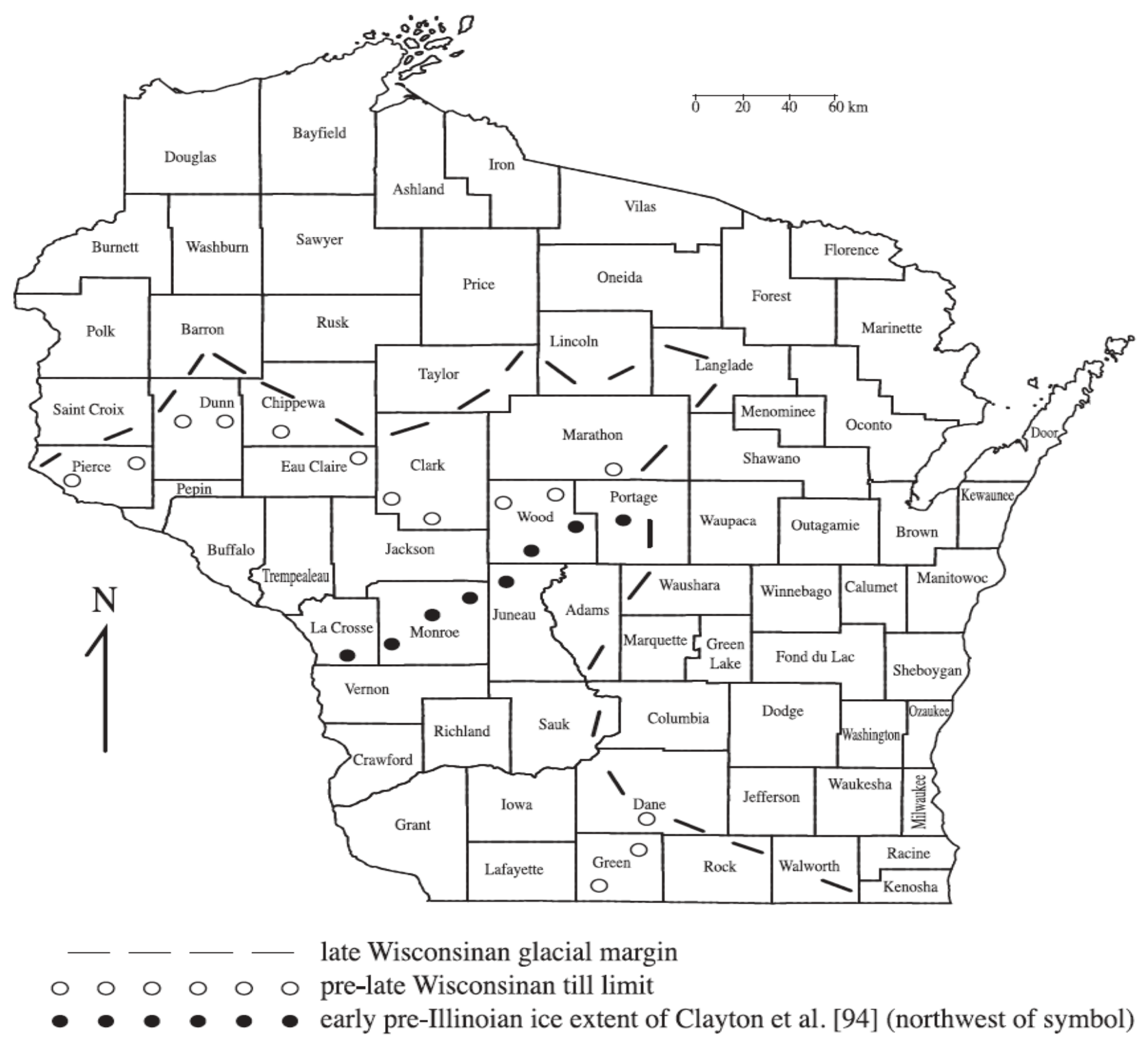

Fig. (2). County map of Wisconsin. Data from Clayton et al. [94].

Driftless Area and dips slightly southwest off the Wisconsin Arch in its western half [3]. Widespread glaciolacustrine sediment from Pleistocene proglacial lakes was deposited in the northeast [22] and southeast quadrants of the Driftless Area in Wisconsin [16] (Fig. 1). Outwash is found on the eastern side of the Driftless Area [22] (Fig. 1). The Paleozoic Plateau is a continuation of the upland Paleozoic bedrock of the Driftless Area but occurrences of pre-Illinoian till range from negligible to patchy and then to increasingly widespread west of the Mississippi River through the Paleozoic Plateau and into the Iowan Erosion Surface [23] (Fig. 1). Pre-Illinoian till completely covers the upland bedrock there (Fig. 1). A variable amount of loess blankets large portions of the Driftless Area [17], Paleozoic Plateau, Iowan Erosion Surface and the Midwest in general [24].

\section{PALEOPERIGLACIAL SLOPE EROSION BY SNOWMELT SHEETWASH AND SOLIFLUCTION (S.S.S.)}

It has long been recognized that Pleistocene solifluction and slopewash have played an important role in eroding the region of the Driftless Area [5, 16, 22, 26]. The scarcity of in-situ red clay residuum on uplands in some areas of this region has been attributed to removal by accelerated mass wasting and slopewash during periglacial phases of the Wisconsinan Glacial Stage [16, 25]. Wherever the red clay does appear in the Driftless Area, at least its A1 horizon is absent [6] (Fig. 3).

Stone-lines in the study area are considered to be erosional lags from slopewash [11] (Fig. 4), especially from destabilized slopes [5]. Sometimes the stone-lines appear to 


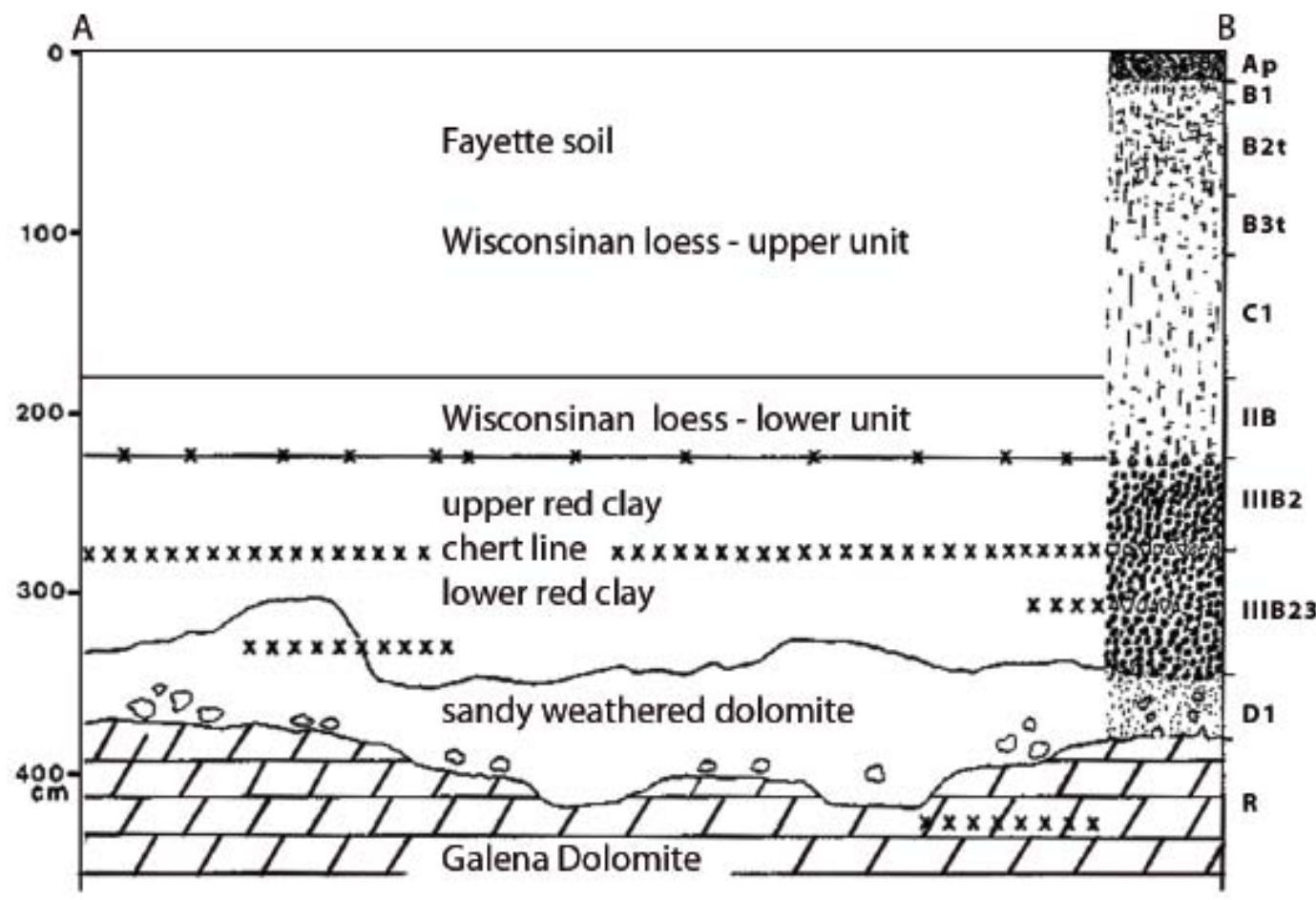

north

south

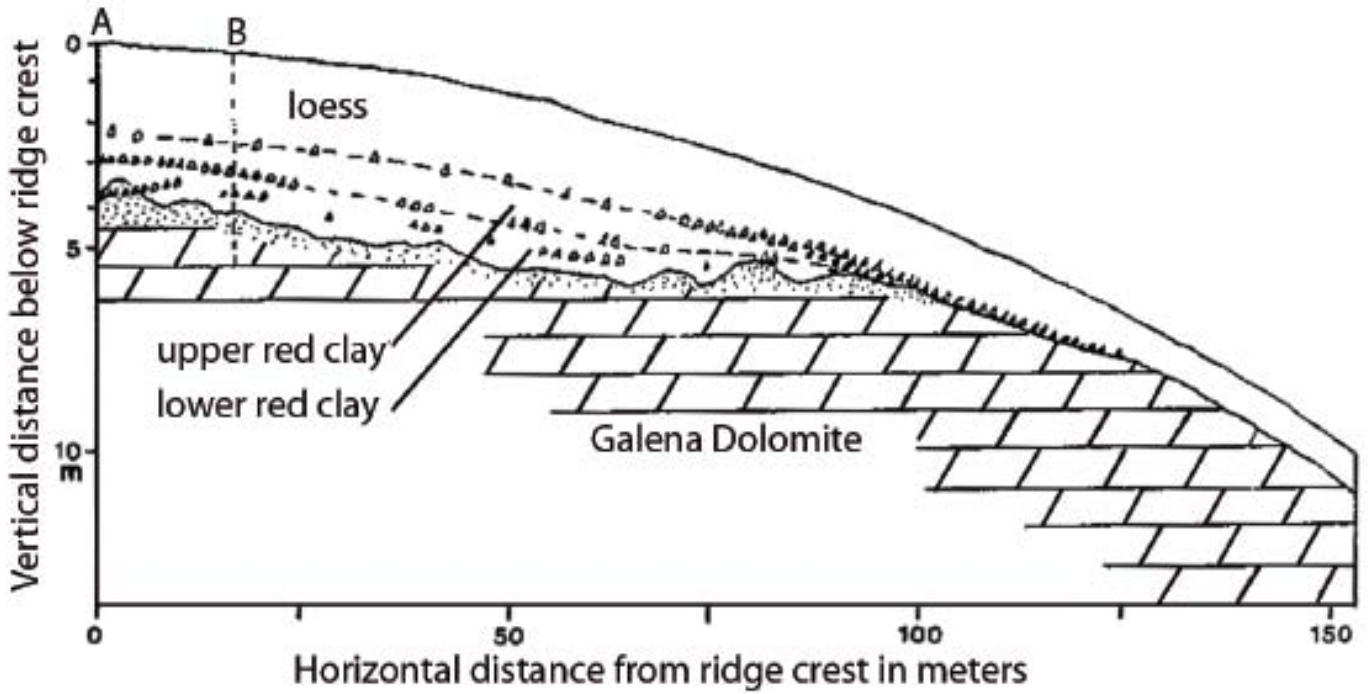

Fig. (3). Soil profile of an upland in the Driftless Area that shows an absence of the entire A horizon material at the top of the upper red clay. The upper red clay is the 2 nd parent material overlain by the 1 st parent material which is a lower unit of the Wisconsinan loess. In-situ stoneline type (chert line) is present within the red clay, and within the Galena dolomite bedrock as a stratum. From Frolking [6]. Reproduced through the courtesy of the Wisconsin Geological and Natural History Survey.

be in situ layers within the red clay residuum in the Driftless Area [6] (Fig. 3). Stone-lines have been characterized, in general, as a buried pedisediment found on Quaternary periglacial erosional landforms [27] and specifically as such within the Iowan Erosion Surface [28]. Till clasts are found in the stone-lines of the till-covered I.E.S. [2] but no till clasts have been observed in the Driftless Area $[5,6]$. Iannicelli [19] proposed snowmelt as the causal agent for the ubiquitous, erosional lag-type stone-line of the Midwest. 


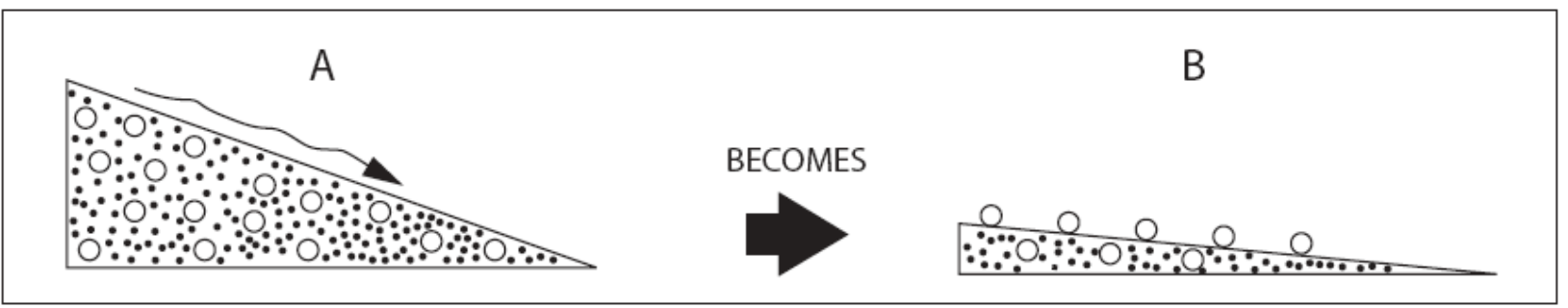

Fig. (4). Diagram depicting non-in situ stone-line genesis. Sheetwash runs over frozen ground composed of diamicton in (A). Downwearing of the slope occurs while fine grains are winnowed out by the sheetwash. This results in an almost level, thin layer of lagged, coarse clasts at the surface in (B). Post-formational burial may or may not accompany this feature.

Table 1. Description of Bedrock Groups and Formations that are Referred to in the Text.

\begin{tabular}{|l|l|}
\hline \multicolumn{1}{|c|}{ Bedrock Unit } & \multicolumn{1}{c|}{ Description } \\
\hline \hline Undifferentiated Silurian bedrock & dolomite \\
\hline Ordovician Maquoketa Formation & shale and dolomite \\
\hline Ordovician Galena Group & dolomite and limestone \\
\hline Ordovician Sinnippi Group & $\begin{array}{l}\text { dolomite with some limestone and } \\
\text { shale }\end{array}$ \\
\hline Ordovician St. Peter Formation & $\begin{array}{l}\text { sandstone with some } \\
\text { conglomerate, shale and limestone }\end{array}$ \\
\hline $\begin{array}{l}\text { Ordovician Prarie du Chien } \\
\text { Group }\end{array}$ & $\begin{array}{l}\text { dolomite with some shale and } \\
\text { sandstone }\end{array}$ \\
\hline Cambrian Wonewoc Formation & sandstone \\
\hline Cambrian Eau Claire Formation & sandstone, siltstone and shale \\
\hline Cambrian Mt. Simon Formation & $\begin{array}{l}\text { sandstone, conglomerate, siltstone } \\
\text { and shale }\end{array}$ \\
\hline Precambrian Baraboo Formation & quartzite \\
\hline Data from: Frankie and Nelson [3]; Sloan and Austin [104] and Laberge [105].
\end{tabular}

Deposits from paleoperiglacial mass wasting and slopewash erosion have been observed in the Driftless Area. For instance, Whittecar [29] identified mass wasting material in the Driftless Area as a solifluction deposit along the East Branch Pecatonic River valley, dated at 40,500 YBP. Also, thick colluvial terraces along a valley side in Grant County, WI (Fig. 2) were dated at only 20,270 YBP [5]. These examples indicate that mass wasting was substantial in just the late Wisconsinan.

Paleoperiglacial mass wasting (solifluction) occurred concurrently with slopewash in the form of sheetwash [30] because a permafrost table (or at least a seasonal frost table) acted as a barrier to infiltration. This concurrent solifluction and sheetwash erosion was the same permafrost active layertype mass wasting that caused widespread, areal stripping of glaciated terrain in western, central and southern parts of Wisconsin, as reported by Clayton et al. [31]. In the Driftless Area, it is expected that the mass wasting would have been expedited by repeated snow blanket melting episodes. Knox [30] affirmed that snow was the foremost precipitation process in the region during the Wisconsinan because alluvial fans from that time contain few pebbles, cobbles and boulders, suggesting a lack of Wisconsinan-age high intensity thunderstorms. Furthermore, Mickelson et al. [25] claimed that perennial snowfields possibly existed in the Driftless Area but added that better indications of this are needed. It is proposed here that the solifluction and snowmelt sheetwash erosional process caused a constant sloughing-off (peeling-off) of surficial material (Fig. 5). Solifluction could have even acted on hilltops with negligible inclinations (slopes with $>0^{\circ}$ inclination) [32].

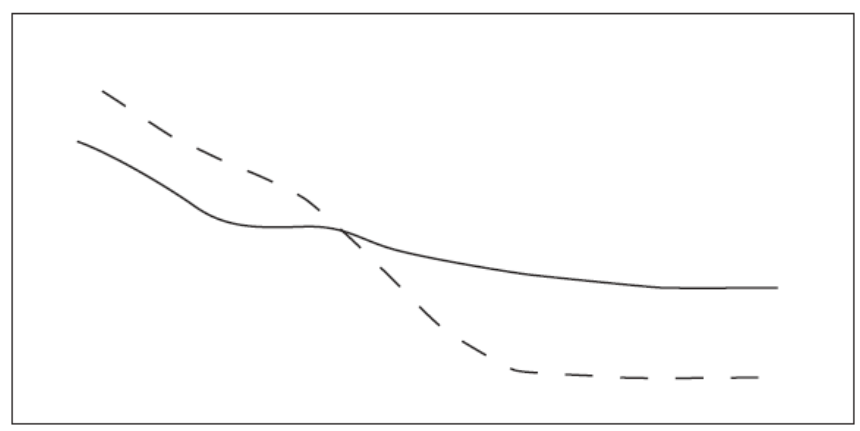

Fig. (5). Simple sketch based on French [106] showing the net result of a field study done on an unlithified, Pleistocene periglacial slope that evolved through solifluction and slopewash processes. Dashed lines represent the original inclinations of the slope. Solid line represents a decrease in the gradient of the original slope after both processes reduced the slope angles measurably. Notice that downwearing and retreat occurred on the upper slope while the lower slope became virtually level after accumulating solifluction and slopewash deposits.

The same processes contributed to denudation of the terrain in areas adjacent to the Driftless Area and the following investigators exemplify this. Frye et al. [33] reported intensive solifluction and sheetwash erosion occurred in northwestern Illinois during the Wisconsinan Glacial Stage. Anderson [2] and Prior [7] reported an absence of paleosol between the bedrock and loess of the Paleozoic Plateau and attributed this to the same erosion that caused the Iowan Erosion Surface. This complements Mason and Knox [34] who described Wiconsinan-age colluvium from solifluction on the Paleozoic Plateau. Hallberg et al. [9] illustrated the truncation of paleosol by the Iowan Erosion Surface while Anderson [2] and Prior [7] illustrated relict colluvium on the Iowan Erosion Surface. Walters [35] reported that solifluction, overland flow and wind erosion brought about severe reduction of the landscape along the Iowan Erosion Surface during this same time. Pleistocene cold-dry phase wind erosion is thought by some to have been intense in the Midwest [4] with the continuity of the loess cover suggesting that Pleistocene running water erosion had little affect on the landscape. However, Ruhe et al. [36] 
concluded that loess deposition coincided with the time of running water erosion in the Midwest and that wet and dry climates were closely related in time during cold phases of the Pleistocene in the Midwest.

To recap, it is proposed that Pleistocene solifluction and snowmelt sheetwash activity from multiple episodes of snow blanket melting led to planar stripping that formed flattened surfaces in the study area. This is coupled with the dissection of the surface by the multiple melting episodes of oriented (paleo) snow dunes. The snow blanket and snow dune melteroded landforms, which often entwined and overprinted on each other, are the focus of the remainder of this report.

\section{NORTHWEST - SOUTHEAST ORIENTED VALLEYS}

Northwest - southeast (NW-SE) linear valleys at a variety of scales are observed at a number of locations within the study area $[19,20]$ (Fig. 1). Valleys up to over $3 \mathrm{~km}$ in length, up to over $1 \mathrm{~km}$ in width and up to $45 \mathrm{~m}$ deep, occur in pre-Illinoian till northwest of Oxford Junction, Jones County in northeastern Iowa [37] within a region called the Southern Iowa Drift Plain (Fig. 1). This region is mostly a rolling or unleveled expanse of till in contrast to the Iowan Erosion Surface which is mostly a planed expanse of till [7]. In northwestern Iowa, NW-SE-oriented linear, loess landforms with similar dimensions were termed by Hallberg [38] as "wind-aligned drainage". Wayne [39] and Wayne and Guthrie [4] correlated those landforms with nonglacial fluted, erosional topography located in Nebraska and South Dakota. This topography also cuts into pre-Wisconsinan till and bedrock, besides the loess $[19,39]$. The oriented valleys in the Southern Iowa Drift Plain of northeastern Iowa are akin to the oriented valleys of northwestern Iowa because Prior [40] and Anderson [41] correlated the NW-SE erosional trend of oriented valleys in northwestern Iowa to the NW-SE erosional trend of the Iowan Erosion Surface which happens to contain many major NW-SE oriented valleys. This is coupled with the fact of the conspicuous adjacency between the Southern Iowa Drift Plain and the Iowan Erosion Surface. Further discussion on the correlation and origin of these major valleys is presented later in this study. Besides the Iowan Erosion Surface having been formed by running water [11], all the NW-SE "fluted" valleys appear to have been cut by running water rather than wind because an eolian lag is lacking within the valley bottoms [19].

Iannicelli [19] concluded that the NW-SE fluted topography in Iowa was formed by snowmelt from snow dunes that developed transverse (or perpendicular) to (paleo)winds blowing from northeast to southwest off the Pleistocene continental ice sheet. These landforms are equivalent to snow-carved, oriented valleys that also formed transverse to the (paleo)wind in Germany [42], Pennsylvania [43] and islands in the Arctic [20].

In northeastern Iowa, NW-SE oriented valleys cut in till are oblique to the regional southwest to northeast slope [44]. This oblique to regional slope relationship is a distinctive feature of snow dune meltwater-carved, oriented valleys [19, $42,43]$. Such snowmelt valleys are initiated by differential frost heaving $[19,43]$. Frost heave occurs around and away from the perimeter of a snow dune while simultaneous retardation of frost heave occurs underneath the snow dune owing to the insulation property of a thick layer of snow [45]. This combination of events slightly raises the terrain around the snow dune, forming temporary embankments [19]. Thus, snowmelt and snowmelt erosion are oriented along the body of the snow dune rather than the steepest direction of the general slope [19].

Although maximum frost heave is attained within fine material such as loess (silt and fine sand), diamicton material such as till is also conducive to frost heave as long as fine grain material is a constituent within the diamicton [46]. Marsh [43] reported the interaction of snow and differential frost heave within either till, colluvium and debris flow deposits helped carve oriented nival valleys in Pennsylvania during the Pleistocene. These were also formed irrespective of the steepest slope direction. It should also be noted that the alignment of some oriented, nival valleys may resemble a dendritic type of drainage pattern (Fig. 6) because some subparallel snow dunes exist beside parallel snow dunes, and so, snow dune melt will inevitably intersect causing a dendritic appearance.

On the Iowan Erosion Surface, there are several larger scale (over $200 \mathrm{~km}$ long and up to $5 \mathrm{~km}$ wide) NW-SE oriented major valleys (Fig. 7) cut in pre-Illinoian till that are too large to be simple snow dune- melt erosion valleys. Also Prior et al. [47] mentioned that these major valleys (such as the Shell Rock River, Cedar River, Wapsipinicon River, etc.) follow the trends of sub-cropping bedrock units, leaving the implication that the till valleys are related to underlying valleys cut in bedrock. However, most Iowan Erosion Surface till valleys are independent of buried NW-SE bedrock channels [48] and the till valleys are carved at right angles to the general slope as noted previously [44]. The large widths and lengths of these major till valleys will be discussed further in the river valleys and wind sections respectively of this study.

In the Driftless Area, within Grant, Iowa and Lafayette Counties of Wisconsin (Fig. 2), Judson and Andrews [14] reported NW-SE-oriented bedrock valleys (Fig. 1) with dimensions (several $\mathrm{km}$ long, $300 \mathrm{~m}$ wide and $50 \mathrm{~m}$ deep) similar to those of the oriented snow dune melt valleys discussed above. They were puzzled that NW-SE valleys dominated NE-SW valleys in a region that is underlain by predominant NE-SW joint control. They suggested that the jointing may be more easily excavated in a NW-SE direction or more intensively jointed in that direction. Similar NW-SE oriented valleys abound in southern Juneau County as reported by Clayton [22] (Figs. 1, 2) and he speculated that either weak cementation or a probable NW-SE fault was the cause.

These NW-SE bedrock valleys in the driftless area are more likely to have been formed by paleoperiglacial erosion with similar forms cut in Wisconsinan glacial deposits immediately to the northeast of the Driftless Area having been attributed to such erosion. Clayton and Attig [49] and Clayton et al. [50] proposed that paleopermafrost perched a water table to initiate carving of NW-SE-oriented dry gullies and channels into drumlins and outwash in Wisconsin during Wisconsinan time. This patterned dissection upon the drumlins and outwash suggest that snow dune melt erosion was in operation even during the recession of the Wisconsinan glacial ice front. In the Driftless Area, melt 


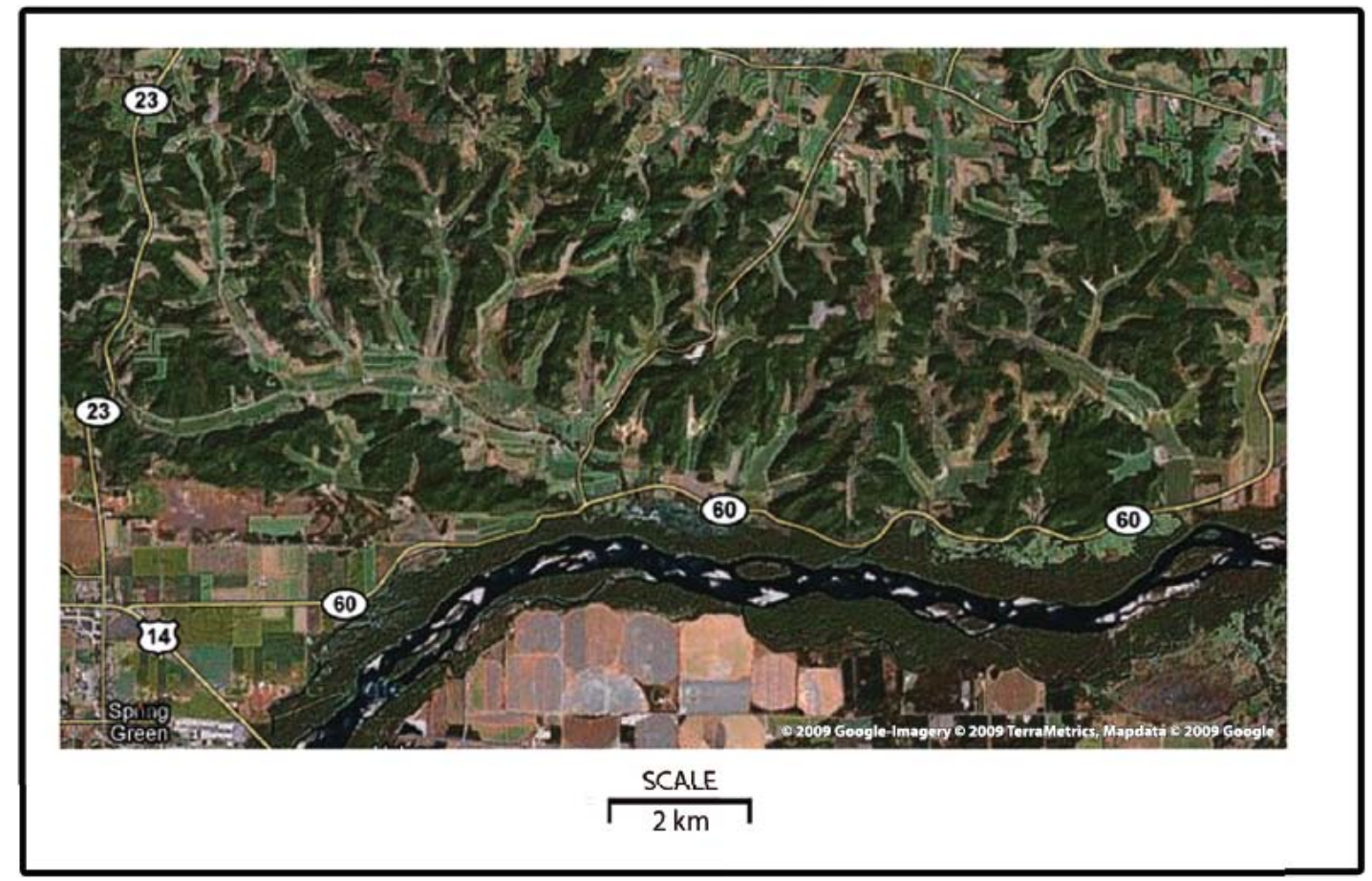

Fig. (6). Aerial photograph of a network of relatively small NW-SE valleys and their resemblance to formal dendritic drainage. Located immediately north of Spring Green, WI which is within the Driftless Area. Trunk valley of the Wisconsin River appears in the lower-half of the image. Reproduced through the courtesy of Google-Maps.

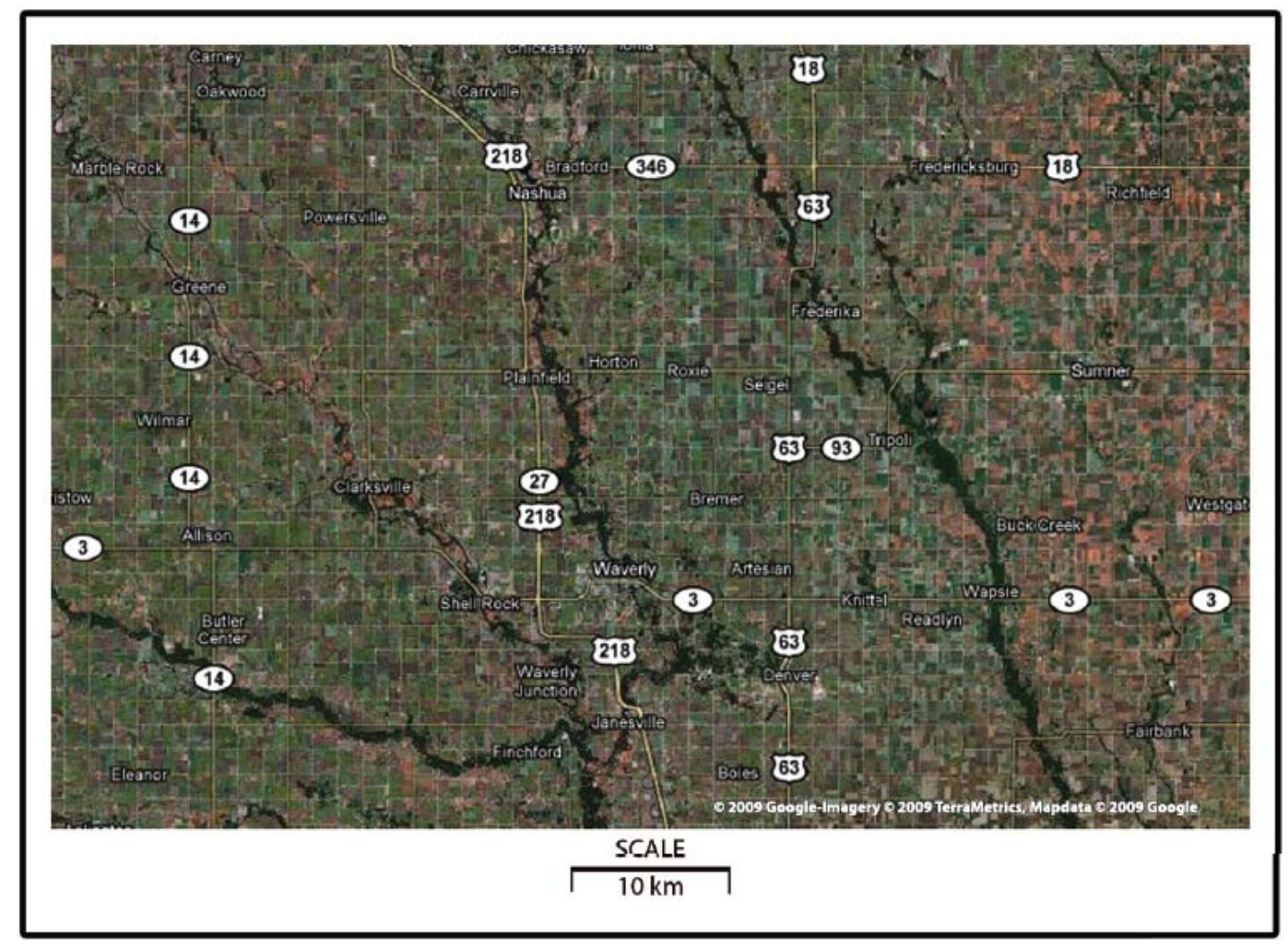

Fig. (7). Aerial photograph of major NW-SE valleys located within the Iowan Erosion Surface. Clockwise starting from left is the West Fork Cedar River, Shell Rock River, Cedar River and the Wapsipinicon River with the East Fork Wapsipinicon River attached to it. Reproduced through the courtesy of Google-Maps.

from snow dunes transverse to the paleowind blowing southwest from off the continental ice sheet [19] could have been the primary erosional agent for NW-SE-oriented valleys (as discussed earlier). 


\section{ILLINOIS-TYPE PAHA}

NW-SE oriented ridges called Illinois-type paha occur near the Driftless Area of Illinois [19, 20, 51] (Fig. 1). They have a loess composition, a height of up to $12 \mathrm{~m}$, and only NW-SE curvilinear lowlands between them, similar to the NW-SE valleys of the other areas that were discussed earlier. Flemel et al. [51] concluded that the Illinois-type paha are dunes. However, dunes only form from saltation transport while true loess simply falls out of suspension (like dust) $[20,52]$. Busacca [53] concurred with this and reported that loess does not form dunes. Iannicelli [20] reasoned that the regional inter-paha loess tracts of Illinois are erosional, formed like the previously discussed NW-SE valleys through snow dune erosion. This left the paha standing as landforms of positive relief. The small height of Illinois paha resulted from vertical erosion not cutting through the entire blanket of loess [20]. Thus, erosion did not reach into the till beneath the loess.

Iannicelli [20] covers basic processes of embryonic paha development (Fig. 8). Multiple, patterned, oriented, transverse, active snow dunes cut and occupy linear to curvilinear valleys carved into till and bedrock on Devon Island, and this modern-day periglacial landscape can be used as an analog for the relic Illinois-type paha landscape in northwest Illinois [20]. The curvilinear valleys on Devon Island intersect one another, and cause segmentation of the snow dune meltwater interfluves that results in individual paha. Iannicelli [20] illustrated a set of snow dune meltwater valleys and paha plus ubiquitous sets of the same landforms lying both adjacent to them and away from them over a very wide, extensive area on Devon Island.

\section{ISOLATING THE PAHA BY CRYOPEDIMENTATION}

\subsection{The Cryopedimentation/Cryoplanation Process}

Priesnitz [54] described the process of cryoplanation/cryopedimentation as erosion under the edge of a snowbank at a riser with solifluction and slopewash transporting frost-shattered debris across the tread and out of the area. The stages of cryoplanation (Fig. 9) and cryopedimentation either progressively result in terracing or ultimately in flattening of a landscape. Cryopedimentation produces large scale features and may require $100 \mathrm{~K}$ years to level relief within a lowland while cryoplanation works at a smaller scale and may require only $10 \mathrm{~K}$ years to bevel hilltops [54]. Although solifluction implies wet conditions, Grosso and Corte [55] reported that frost- shattering processes leading to cryoplanation, are strongest in dry cold deserts under continental climates. These conditions can cause the recession of those scarps that have very tall, vertical cliff faces because of simple rockfall from the weathering [45]. Thus, cryoplanation/cryopedimentation may have been in operation during wet and dry phases (under periglacial conditions) of the Pleistocene within the Midwest although one climatic phase may have intensified these processes more than the other climatic phase.

It is already known that weathering rates of periglacial realms are slow and that long-term snowmelt erosion rates simply do not exist in the literature [56]. However, this did not prevent other geoscientists such as Clark and Hedges [57], Marsh [43], and Iannicelli [19, 20] to propose snowmelt as the cause for large, relict, nival landscapes. Clark and Hedges [57] cited criteria for the identification of Pleistocene cryoplanation such as: erosional discordance to

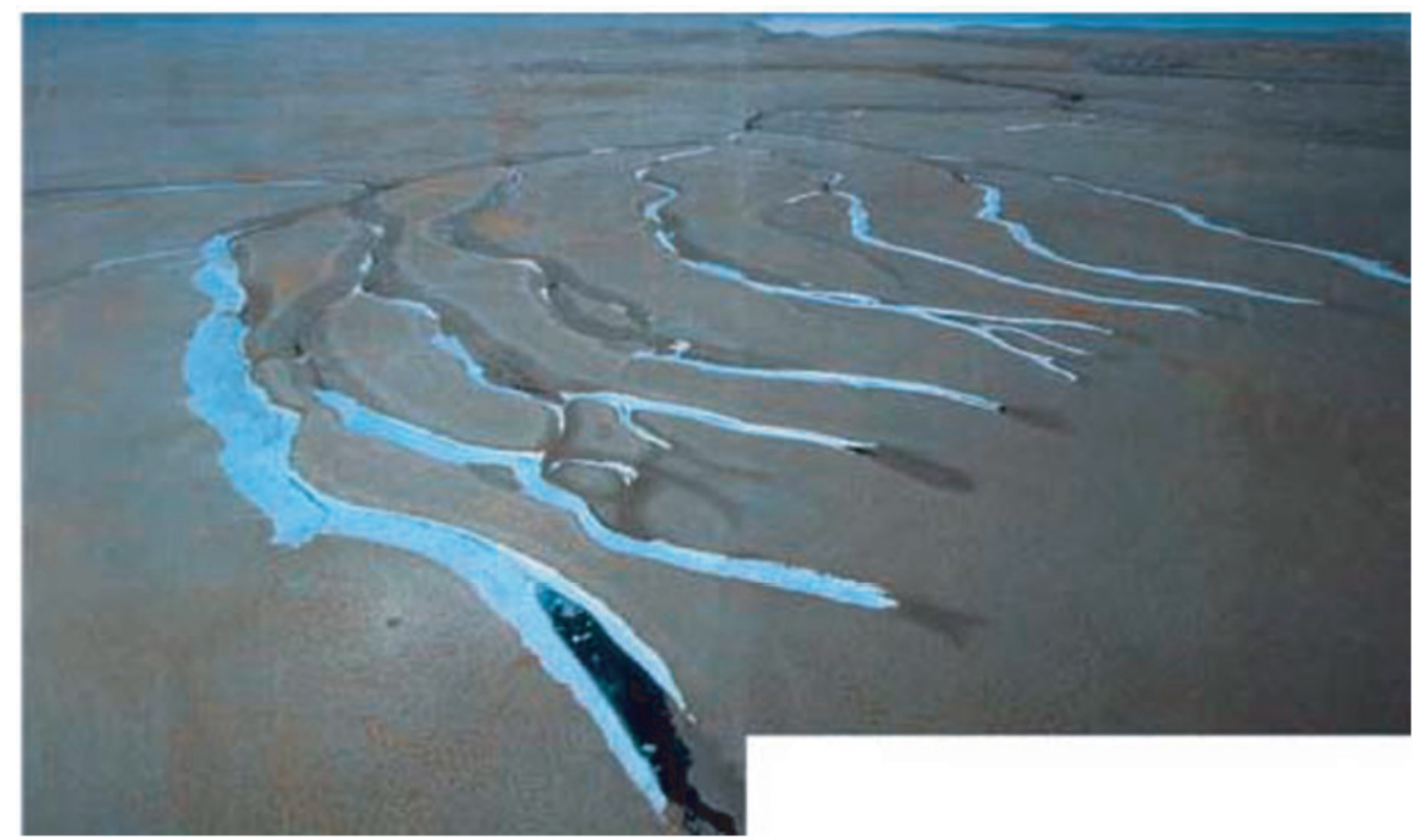

Fig. (8). Landscape of Devon Island, Nunavat in the high Arctic that exhibits Illinois-type paha. Note how the snow dune-occupied valleys intersect, causing dissection of the snow dune meltwater interfluves into individual paha. Foreground landscape is approximately $2 \mathrm{~km}$ wide. North is toward the top. From Long [107]. Permission to duplicate granted by Peter Essick/Aurora. 


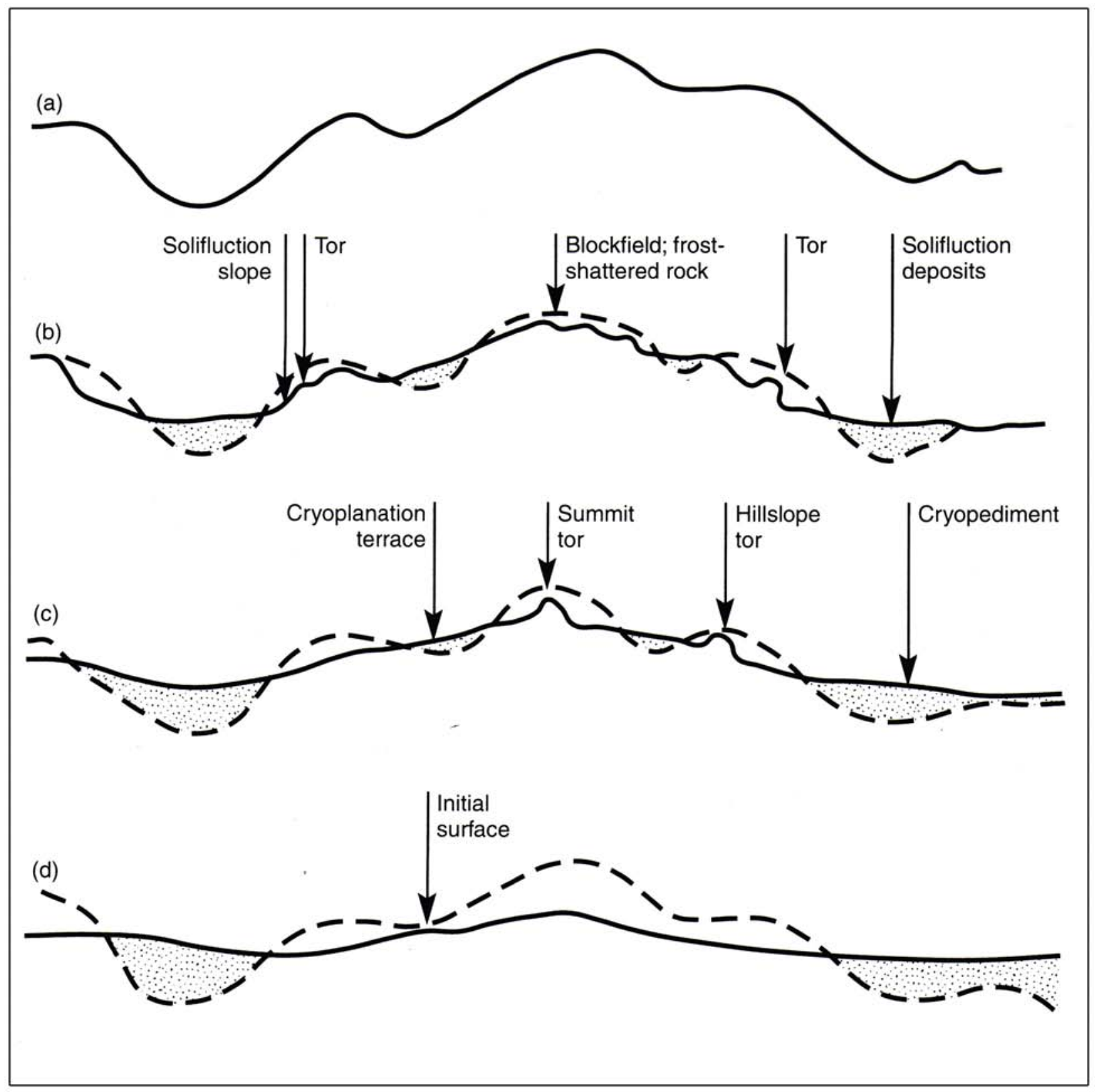

Fig. (9). Stages in flattening of a bedrock landscape by cryoplanation and cryopedimentation: (a) initial surface; (b) slope inclinations begin to decrease through nival erosion and deposition; (c) mature profile; (d) and end stage. Note rough domal profile in (c) and a more subtle shield profile in (d). From French [45]. Permission to duplicate granted by Hugh French.

either structure or bedding; the existence of relict colluvium; and accordant elevations of flat surfaces. Another criterion is certain lithologies such as resistant outcrops that are capable of producing rubble (i.e., quartzite) [54].

\subsection{Iowan Paha}

Isolated, NW-SE-oriented ridges overlying the Iowan Erosion Surface plain are interpreted as remnant, snow dune meltwater interfluves [19] (Fig. 1). They are called paha and consist of pre-Illinoian till capped by loess. Dimensions are up to $12 \mathrm{~km}$ in length [11], up to $2 \mathrm{~km}$ in width [11,58], and up to $36 \mathrm{~m}$ in height [59]. Although Iannicelli [19] invoked Pleistocene nival flooding to account for the broad plain of the Iowan Erosion Surface, the perception now is that cryopedimentation formed the plain of the Iowan Erosion
Surface during or after snow dune erosion carved out the depressions between paha ridges. This is in agreement with Hallberg et al. [28] who suggested that the Iowan Erosion Surface and the Silurian Escarpment (Fig. 1) resulted from "non-classical" pedimentation, namely sheetwash under nonarid conditions.

\subsection{The Sand Flats Cryopediment and Rock Paha}

A lowland known as the sand flats of the Driftless Area (Fig. 1) was analyzed by Clayton and Madison [60]. They described it as a flat, vast expanse of Cambrian Mt. Simon Formation sandstone. It is composed of two halves. The western half covers the eastern half of Jackson County, WI and parts of north-central and northeastern Monroe County, WI (Fig. 2), and starts approximately from the Black River 
east to its divide. East of the divide begins the eastern half of the sand flats which is named the central sand plain. The western side of the sand flats is covered by a few meters of "presumable fluvial sand" derived from surrounding Cambrian sandstones, including pebbles and cobbles of chert derived from Ordovician dolomite within the uplands [60]. Today, many bogs lie on the west side of the sand flats because the water table is held up by clayey layers within the underlying Mt. Simon Formation sandstone. Much of the eastern half of the sand flats is covered by sediments from glacial Lake Wisconsin that stood in front of the Wisconsinan glacial ice limit [22] (Fig. 1). The proglacial lake covered much of Juneau and Adams Counties, WI, extending west into eastern Monroe County and north into the southern parts of Wood County and Portage County, WI [22] (Figs. 1, 2). Clayton and Madison [60] hypothesized that the sand flats erosion surface are relict periglacial pediments (or cryopediments, see [54] ). Ubiquitous, NWSE-oriented, parallel, oblong, isolated outliers of sandstone and similarly aligned, Precambrian inliers lie over the sand flats [12] (Figs. 1, 10). Examples can be found in 1:24,000 scale, WI quadrangles such as the Hatfield SE quad (Crawford Hills), Spaulding quad (Drescher Island) and the City Point quad (Birch Bluff and VanTassle Island). Clusters are seen on 1:62,500 scale maps such as the Kendall, WI quad. Dimensions of these landforms range up to $10 \mathrm{~km}$ in length [12], up to $1 \mathrm{~km}$ in width [12], and up to $40 \mathrm{~m}$ in height (see Warrens West, WI ((1:24,000 scale)) quadrangle). They also dot the uplands of the Driftless Area in Wisconsin such as Platte Mound near Platteville and Grandad Bluff near Lacrosse. Similarly, isolated, NW-SEoriented mounds of rock are found in the uplands of the Driftless Area in Illinois [3] (Fig. 1). A key observation by Flemal et al. [51] uncovered a small number of Illinois-type paha having a core of bedrock with only a capping of loess. The isolated inliers and outliers on the sand flats and on the uplands are termed in this study as "rock paha" based on the correlation to the Iowan and the Illinois-type paha discussed earlier.

\subsection{Paleopermafrost Table Promoted the Planation Process}

Cryoplanation and cryopedimentation are promoted because the permafrost table acts as a "local baselevel" by blocking infiltration [61] (Fig. 11A). Solifluction is intensified whenever a permafrost table co-exists with it because impeded infiltration causes water-logging of the regolith. French [45] noted that insulation of the ground by snow cover would cause the permafrost table to deepen. Over time, the snow and snowmelt-deepened paleopermafrost table would have permitted additional infiltration (Fig. 11B) that probably slowed snow dune erosion, cryoplanation and cryopedimentation. Disappearance of the snow would have re-elevated the permafrost table and the cycle would repeat itself whenever snow arrived during the cold phases of the Pleistocene. A variant

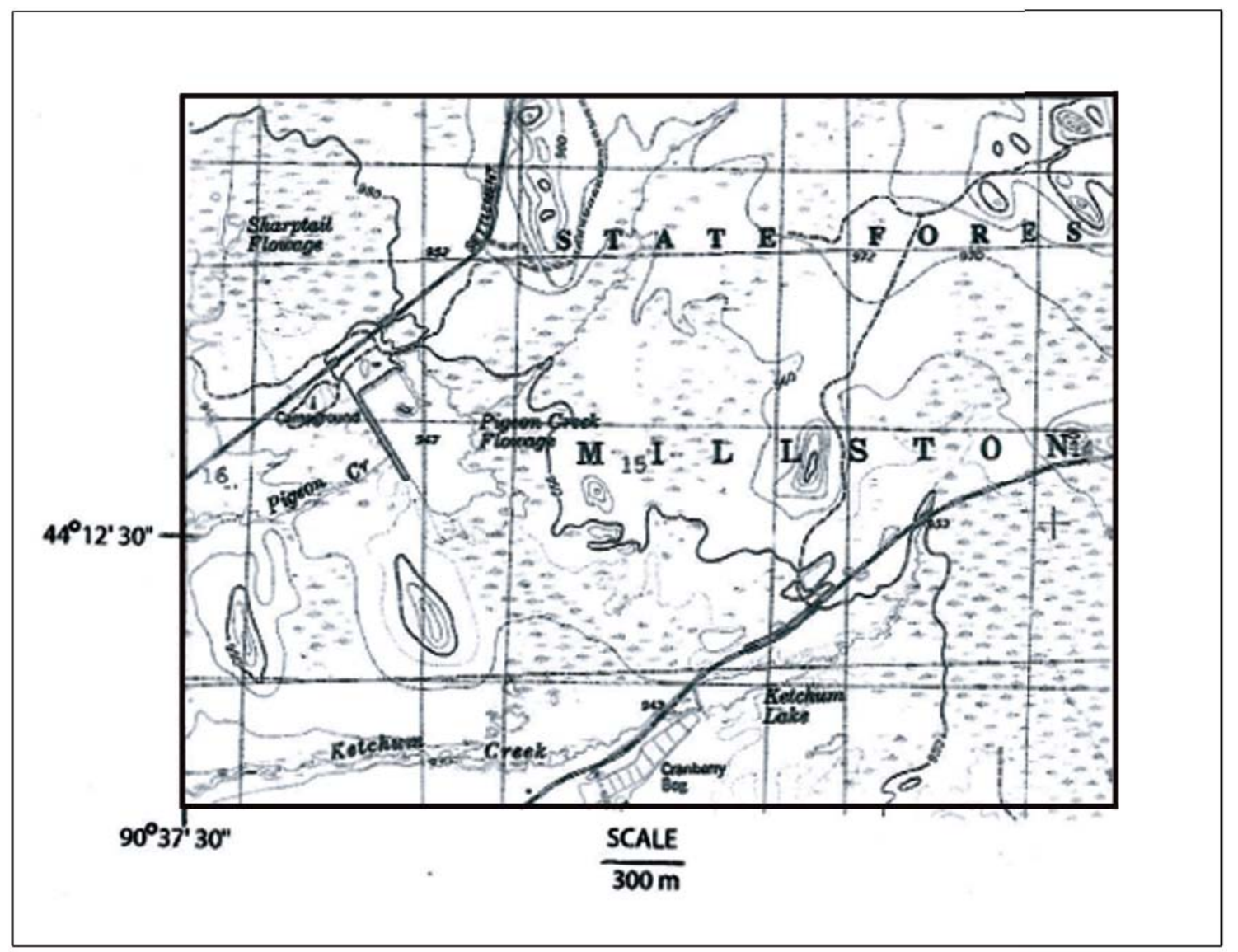

Fig. (10). Isolated, sizable, NW-SE rock paha lying on the sand flats. Larger ones are on the left side while smaller ones exist on the right side of map. Portion of the Warrens West, WI (1:24,000 scale, 10-ft. contour interval) quadrangle. North is towards the top. Reproduced through the courtesy of the Wisconsin Geological and Natural History Survey. 
of this is, if the snow freezes at the base because of some melting and subsequent refreezing, then the permafrost table keeps its position, retarding infiltration (Fig. 11C).

The existence of a widespread permafrost table in the study area is shown by indicators of permafrost such as ice wedge casts (which require only a few hundred years to form) scattered over much of the Driftless Area [17] and the Iowan Erosion Surface [35]. Walters [35] illustrated the stone-line of the I.E.S. trending over and dipping slightly across the tops of some ice wedge casts. This implies that the Iowan Erosion Surface was forming just before complete infilling of the wedges, indicating that mass erosion and paleopermafrost were closely related in time.

\section{OTHER CRYOPEDIMENTATION/CRYOPLANATION LANDFORMS}

\subsection{Baraboo Hills Summit Plateaus and Terraces}

The Baraboo Hills in Sauk County, WI (Figs. 1, 2) are composed of very hard quartzite and they exhibit a variety of features that can be interpreted as cryoplanation landforms. In the town of North Freedom in Sauk County, WI, Clayton and Attig [26] reported a quartzite upland with terraces cutting across the dip of the quartzite. They also reported frost-shattered fragments of quartzite including boulders on summit plateaus within the South Range of the Baraboo Hills. East Bluff, a quartzite upland adjacent to Devils Lake, has castellated cliff features that truncate obliquely across the bedding of the quartzite [62]. The quartzite composition of the landform satisfies the lithological criterion of cryoplanation which is resistant rocks that are capable of producing rubble [54]. Quartzite talus blankets the tread up to the foot of the cliff [62], and Black [62] claimed that the talus is Wisconsinan in age. Black [62] also claimed that ubiquitous pinnacled cliffs are Wisconsinan in age. These features in general, are referred to as "arguilles" on cryoplanated hilltops by Briggs et al. [63]. A smaller tread and riser lies on an adjacent bluff that is also reported by Black [62]. He described it as a $4 \mathrm{~m}$ tall "overhanging bank" that runs through the crest of South Bluff and identified it as a glacial meltwater channel. Clayton and Attig [26] observed that there was no opposite bank and interpreted it as a scarp formed by hillslope processes during the time of permafrost.

\subsection{The Blue Mounds Planation}

West and East Blue Mound are two side-by-side flattopped hills located between Iowa County and Dane County of Wisconsin (Figs. 1, 2) within the Driftless Area. An overburden of non-in situ, resistent, Silurian chert boulders derived from pre-existing dolomite caprock overlays Maquoketa Formation shale on West Blue Mound while East Blue Mound is capped by Maquoketa Formation shale but is missing both the chert armor and $40 \mathrm{~m}$ of shale [16]. This implies that erosion discordantly bevelled across lithologies. Mickelson et al. [25] thought that Pleistocene periglacial slope and fluvial processes flattened the Blue Mounds. However, cryoplanation was more likely the planing agent because the size of the non-in situ chert boulders on the slopes argues for mobilization by solifluction rather than fluvial sheetwash.

\subsection{Types of Cryoplanation Landforms}

Distinctive sickle-shaped landforms support cryoplanation as the erosion process shaping the uplands above the sand flats in the Driftless Area and on the Paleozoic Plateau. Upland plateaus in the study area can reach over $10 \mathrm{~km}$ in length and a few $\mathrm{km}$ in width such as the Prairie du Chien plateau in the Paleozoic Plateau region. In general, Clark and Hedges [64] and French [65] reported some present day cryoplanation landforms to be "sickleshaped". Just inside the Driftless Area on the Verona, WI $(1: 24,000$ scale) quadrangle, Clayton and Attig [16]

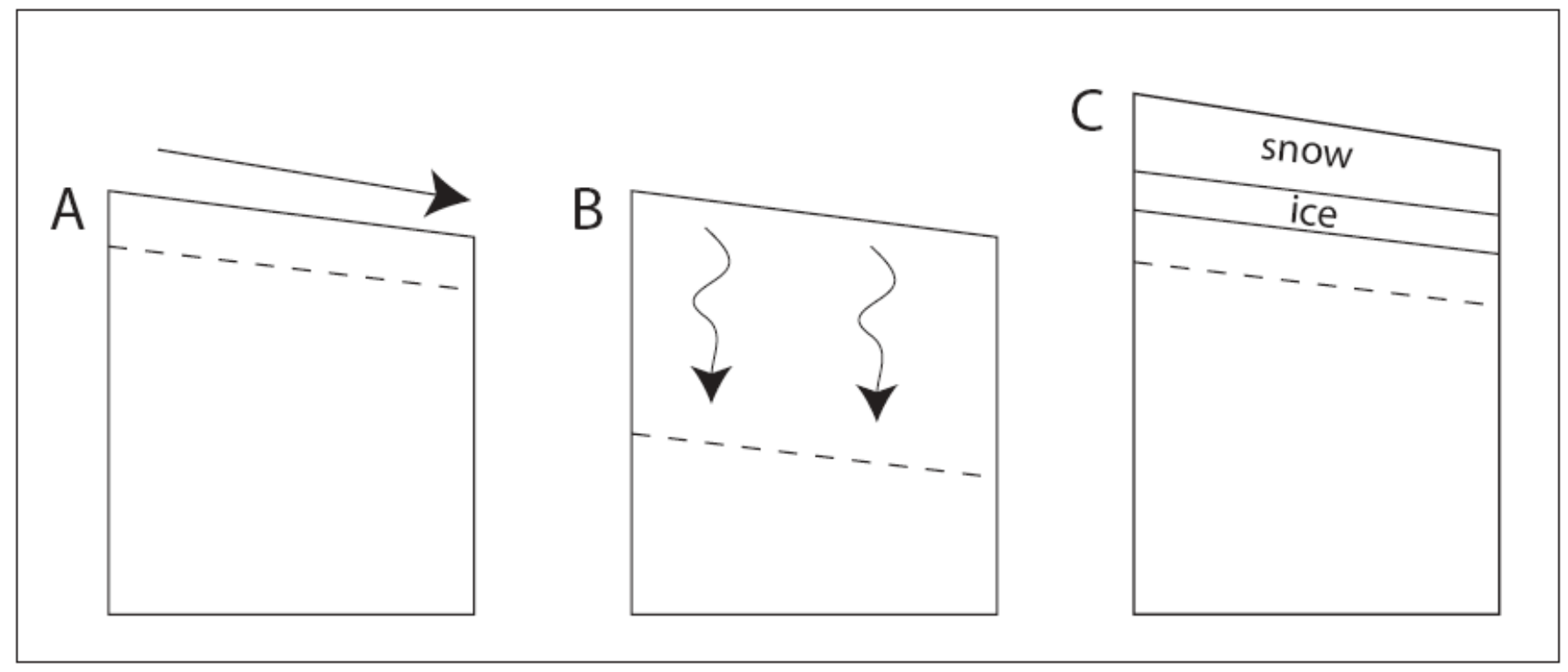

Fig. (11). Putative diagram based on French [45] and Clark [108] showing cycle of snowmelt and snowmelt freezing on permeable sediment that may cause a fluctuating permafrost table. In (A), seasonal snowmelt (arrow) flows over the permafrost table (dashed line). In (B), gradual lowering of the permafrost table (dashed line) due to the thermal property of either snow or snowmelt, allows snowmelt infiltration (arrows). In (C), winter freezing converts snowmelt into ice at the base of a snowpack which allows re-elevation of the permafrost table (dashed line). 


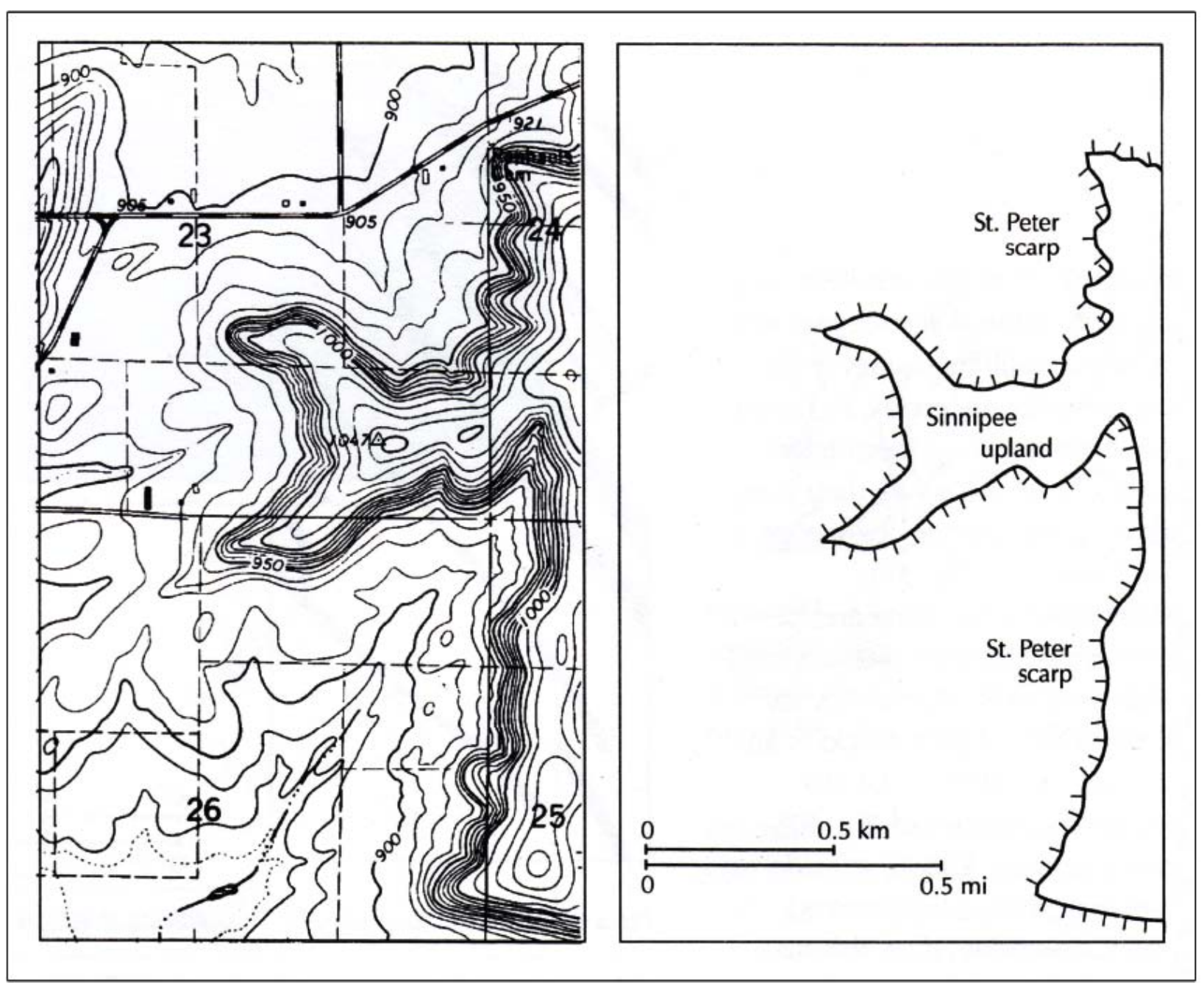

Fig. (12). Scalloped upland showing the sickle-shape configuration. "Sinnipee upland" and "St. Peter scarp" allude to certain bedrock units (see Table 1) that comprise these landforms. Portion of the Verona, WI (1:24,000 scale, 10-ft. contour interval) quadrangle. North is towards the top. From Clayton and Attig [16]. Reproduced through the courtesy of the Wisconsin Geological and Natural History Survey.

illustrated a plateau capped by Sinnipee Group (Table 1) dolomite that appears to be scalloped, causing it to be "sickle-shaped" (Fig. 12). This landform is interpreted to be from the widening of a small valley on the hillside by incipient pedimentation. Map reconnaissance of the Driftless Area shows that sickle-shaped landforms are not uncommon.

Besides the sickle-like landform in the Driftless Area, entire plateaus that cut into carbonate bedrock in Dane County, WI, feature a dome-shape morphology on their summits as illustrated by Clayton and Attig [66]. Grosso and Corte [55] report a carbonate bedrock surface underlying summits within a modern-day periglacial zone, is in the shape of a "convex plain". Reger and Pewe [67] also reported "rounded crests" on hills in Alaska, and attributed it to staircases (terraces) formed on opposite sides of the summit because of cryoplanation that were later rounded by Holocene weathering and erosion.

A single, small domal hill is called a cryoplanation "tump" by Hughes [68] and is slightly larger in dimensions than a typical tor (Fig. 13). Other photographs of a tump appeared in Boch and Krasnov [69] and Hughes [68]. The term is derived from cryoplanated alpine areas such as
Nyatyi Tump Mountain of the northern Urals [69]. In the study area, Clayton and Attig [70] mentioned and illustrated rounded domal tops of upland plateaus. Clayton and Attig [71] described these type plateaus noting their "middles" are about 10 to $20 \mathrm{~m}$ higher. The "middles" are referred to as tumps here, and this conforms (at a slightly larger scale) to the summit tor structure left over during the third stage of cryoplanation (Fig. 9c). Within the Paleozoic Plateau, plateau surfaces of Houston County, MN also show this domal form [72]. A composite of Runkel [73] is domal in configuration featuring small, remnant "crown" plateaus of Galena Group bedrock on top of extensive plateaus of Prairie du Chien Group caprock.

The surficial material gives further evidence for the ending stages of cryoplanation that resulted in the domal configurations of plateaus in the Driftless Area. There is retention of a meter of loess only on the top of the tumps while the flanks of the plateaus are loess-free [70] and are covered with only a veneer of pedisediment [74]. In other words, retreat of the landforms' riser left a lag of pedisediment while on the flat top of the domal tump, erosion has been insufficient to remove the loess. 


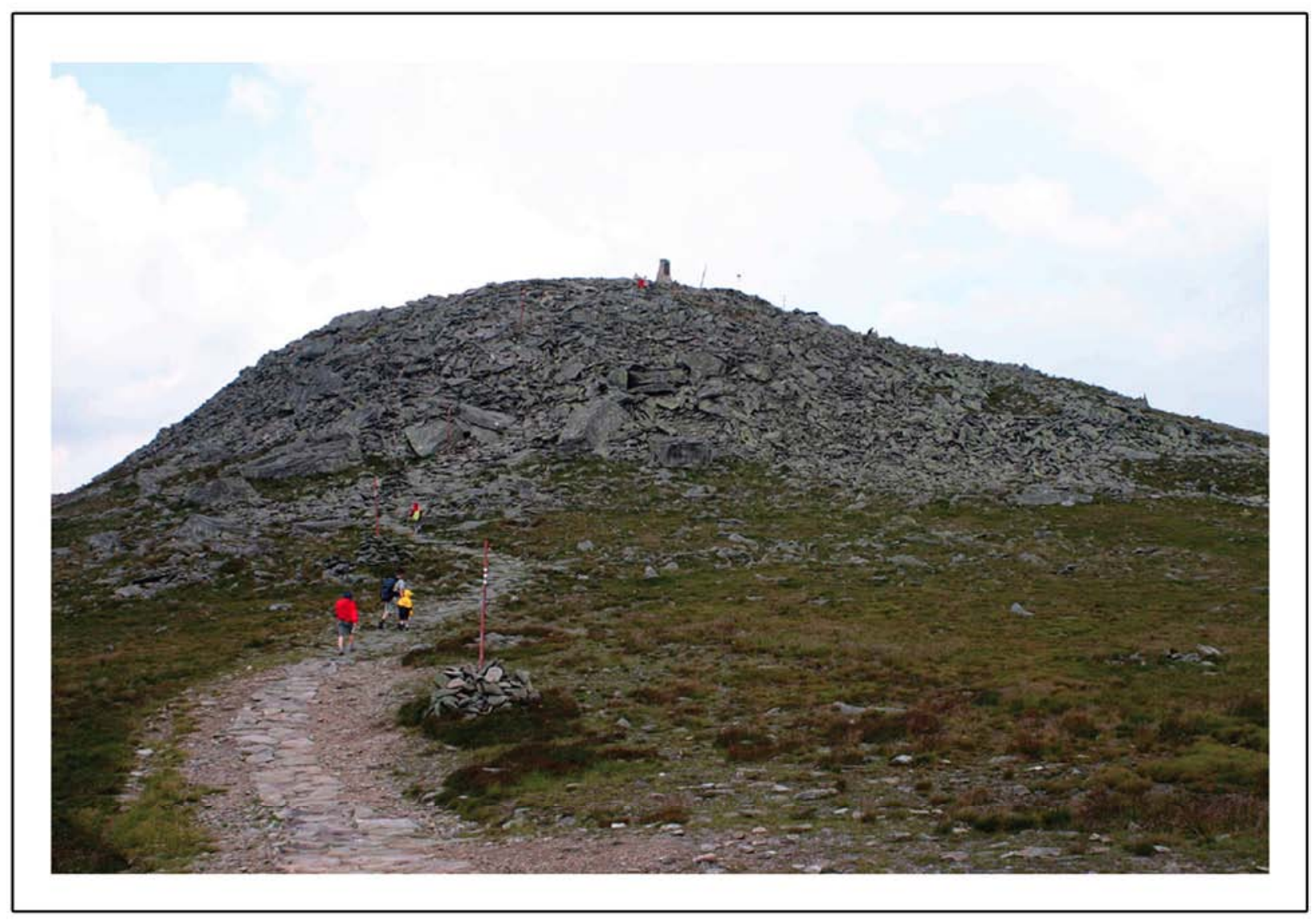

Fig. (13). Excellent, unvegetated example of a cryoplanation tump with a well-developed terrace at Babia Gora mountain. Frost-wedged blocks of sandstone cover the dome-like landform. Other photographs of this same landform (not shown in this figure) show the distal portion of the gentle ramp-like terrace overlain by very large sandstone blocks. The locale was periglaciated [109] and outside of continental glacial ice limits in Europe. People in the middle foreground for scale. Located in the Western Beskidy Mountains at the western part of the High Carpathian Mountains in Slovakia near the border of Poland (49 34' 19" N, 19 31' 23" E). Photographed by Jan Madaras. Permission to duplicate granted by Jan Madaras.

This can be taken further by grouping the rock paha within the category of tumps or "crown" plateaus. The Driftless Area of Illinois encompasses an expansive, dissected flat underlain by Ordovician Galena Group bedrock that equates to the "Lancaster" erosion surface in Illinois; and above this, small remnant hills with flat tops were preserved by a Silurian cherty dolomite cap that is classified as part of the Dodgeville erosion surface $[75,76]$. Wiggers [8] also pointed out that the Dodgeville erosion surface on these same small, remnant hills can be traced acrossed the Mississippi River and are level with the Dodgeville erosion surface on the top of the Silurian Escarpment (Fig. 1) in northeastern Iowa. Many of these remnant hills in Illinois are oriented NW-SE and elliptical in shape (Fig. 1) such as Mt. Sumner, Wenzel Mound, Hudson Mound and several others [3]. They are identified here as rock paha and remain standing on a plateau instead of a pediment such as the sand flats. Another example of this type include isolated, elliptical NW-SE oriented hills overlying the Paleozoic Plateau in Minnesota [13] (Fig. 1) and they have both a flat top [77] and Pleistocene colluvium covering the surfaces on some of them [78]. Thus, these should also be considered rock paha on a plateau (like the Driftless Area of Illinois) (Fig. 1) instead of on a widespread pediment like the sand flats. Interestingly, Fig. (14) exhibits rock paha still partially attached to the main upland which indicates that it didn't evolve completely to maturity (it lacks a surrounding, planated surface).

\subsection{Examples of Pedimented River Valleys}

\subsubsection{LaCrosse River Valley}

River terraces are presumed to be very susceptible to cryopedimentation $[54,79]$. The terrace risers retreat in parallel fashion from both sides of the river until a cryopediment is formed. The form of the upper LaCrosse River valley (Fig. 1) in northern Monroe County, WI (Fig. 2) suggests this type of Pleistocene cryopediment erosion. The narrow, underfit present-day river lies within a wide valley that is underlain by the Mt. Simon Formation sandstone and is flanked by higher-elevated benches of the Eau Clair Formation [12] (Table 1). The very wide, flat, box-shaped valley floor has an extremely gentle gradient and in places is occupied by lakes such as $1 \mathrm{~km}$ long Squaw Lake and $500 \mathrm{~m}$ long Alderwood Lake. The valley becomes a curvilinear flat farther downstream in LaCrosse County [80], and is $6 \mathrm{~km}$ wide between flanking uplands. 
Clayton $^{1}$ remarked that the LaCrosse valley's origin is obscure and that only an insignificant amount of sediment underlies the upper river valley. This compels $\mathrm{Knox}^{2}$ and $\mathrm{Kochel}^{3}$ to note that the bedrock (and not the valley fill) of this valley gave rise to the flat topography here. The thin valley fill in the valley was confirmed by borehole records near the head of the LaCrosse River valley. One locale recorded $6 \mathrm{~m}$ of sand and another locale recorded $12 \mathrm{~m}$ of sand at a distance of 375 and $450 \mathrm{~m}$, respectively, away from the head of the valley (Wisconsin Geological and Natural History Survey (WGNHS) Geologic Log \#MO-242 and Department of Natural Resources Well Construction Report \#IG547, respectively). Three other locales more $10 \mathrm{~km}$ down-valley of the head recorded $11 \mathrm{~m}, 14 \mathrm{~m}$, and $15 \mathrm{~m}$ of sand (WGNHS Geologic Log \#MO-28, MO-31 and MO-41, respectively). All sands were derived from the underlying, friable, Mt. Simon Formation sandstone, and thickness of the sediment is augmented by this friability. The $6 \mathrm{~km}$-width of this mantled valley floor is within the range of widths (100 $\mathrm{m}$ to $10 \mathrm{~km}$ ) reported for widths of active cryopediments by Priesnitz [54]. Furthermore, the flat expanse of the Mt. Simon Formation in this valley is accordant with the surficial Mt. Simon Formation that underlies the vast erosion surface of the sand flats

\subsubsection{Maquoketa River Valley}

Anderson [2] and Hallberg et al. [81] diagrammed the Iowan Erosion Surface not only as a vast, widespread, flattened surface but also as a terrace along river valleys in Iowa. Maquoketa River valley (located roughly between the Paleozoic Plateau and the Iowan Erosion Surface) (Fig. 1) is one example of this [82]. Anderson [2] also illustrated the ubiquitous stone-line associated with the Iowan terrace. The present-day Maquoketa River flows over alluvium that is underlain by Silurian dolomite bedrock. Relict colluvium found along a segment of the Maquoketa River valley is dated at $21 \mathrm{~K}$ to $16 \mathrm{~K}$ YBP [83]. Anderson [2] and Hallberg et al. [81] characterized the Iowan terrace as a Wisconsinanage pediment that cuts into pre-Illinoian till.

Related to this, Ludvigson, et al. [84] reported that the modern-day South Fork Maquoketa River is partially superimposed over a paleovalley. They stated that a high degree of erosion from Wisconsinan pedimentation took place upon the slopes of the paleovalley while thick deposits of slopewash accumulated along the axis of the paleovalley.

\subsection{Extensive Bench Forms}

The Wonewoc and the Eau Clair Formations form two extensive topographic steps or benches that rise above the perimeter of the sand flats $[12,22,26]$ (Fig. 1). These ubiquitous benches are even found far from the sand flats area, occurring in western Wisconsin as mapped by Brown [12]. All three surfaces (the sand flats, the Eau Claire Formation bench and the Wonewoc Formation bench) fall within a range of levels (2-4 levels) that is characteristic of cryopedimentation according to Priesnitz [54]. The benches

\footnotetext{
${ }^{1}$ L. Clayton, (personal comm., 2003), Wisconsin Geological and Natural History Survey, 3817 Mineral Point Road, Madison, WI 53705 USA.

2 J. C. Knox, (personal comm., 2003), University of Wisconsin at Madison, Dept. of Geography, 234 Science Hall, Madison, WI 53706 USA.

3 R.C. Kochel (personal comm., 2003), Bucknell University, Dept. of Geology, Lewisburg, PA 17837 USA.
}

are covered with Pleistocene colluvium (mapped as poorly sorted, silty to gravelly material from mass wasting processes) such as on the Wonewoc Formation bench in LaCrosse County, WI [80]. This further suggests that the benches are a result of cryoplanation/cryopedimentation.

The Wonewoc Formation (Table 1) also caps many flattopped rock paha on the eastern [64] and western sides of the sand flats [12] (Fig. 1). Black [62] showed many photographs and a topographic map of them on the eastern side of the sand flats (the central sand plain) where former glacial Lake Wisconsin stood. The elevation of these flat summits is $>300 \mathrm{~m} \mathrm{ASL}$ and could not have been wave-cut because Clayton [22] reported that glacial Lake Wisconsin only reached $294 \mathrm{~m}$ ASL and its beach deposits presently sit at $295 \mathrm{~m}$ ASL. Also, the lake level of glacial Lake Wisconsin never reached the flat-topped rock paha west of the drainage divide (Fig. 1) that separates the drainage basin of the Black River from glacial Lake Wisconsin. So the preferred process of leveling these landforms remains cryoplanation /cryopedimentation.

\subsection{Cryoplanation Forms Outside the Study Area}

Jungerius [85] concluded that cryoplanation was responsible for creating the Cypress Hills plateau in Alberta, Canada. The plateau is $130 \mathrm{~km}$ long; $9 \mathrm{~km}$ wide; and is divided into three, separate, upland blocks. These dimensions support the concept that cryoplanation can form large scale surfaces. The Cypress Hills plateau and adjacent pediments were nunataks that rose above the late Wisconsinan glacier [86]. Some of the adjacent pediments are isolated, elongated, NW-SE-oriented remnants that lay atop older, larger and broader pediments as illustrated by Jungerius [86]. These forms are here identified as large scale flat-topped rock paha. Another feature common to both the Cypress Hills plateau and Driftless Area regional plateaus is their immediate proximity to the continental ice sheet.

\section{WIND: THE FACTOR CONTROLLING THE AMOUNT OF SNOW DEPOSITON AND S.S.S. EROSION}

The direction of the NE to SW paleowind from the anticyclone over the Laurentide ice sheet (Fig. 1) during the Wisconsinan $[19,87]$ happens to correlate to a NE to SW trend of a declining degree or amount of erosion from the Driftless Area to the Paleozoic Plateau to the Iowan Erosion Surface. There is no trace of till in the Driftless Area. When we move into the SW direction, bevelled hilltops of the Paleozoic Plateau retain a negligible amount of pre-Illinoian till. Further SW within the Paleozoic Plateau, the till increases, displayed as scattered patches until it becomes widely distributed to the SW into the Iowan Erosion Surface [23] (Fig. 1). The pattern of pre-Illinoian till deposits that range from negligible to patchy and then to ubiquitous, thickening increasingly towards the SW [23], points to an erosional control as reported by Prior [88]. This is corroborated by a decrease in relict colluvium to the west [10]. Further evidence is the diminishment of Pleistocene planed landscapes [89] and NW-SE-oriented landforms [7] within the Southern Iowa Drift Plain that are SW of the Iowan Erosion Surface. 


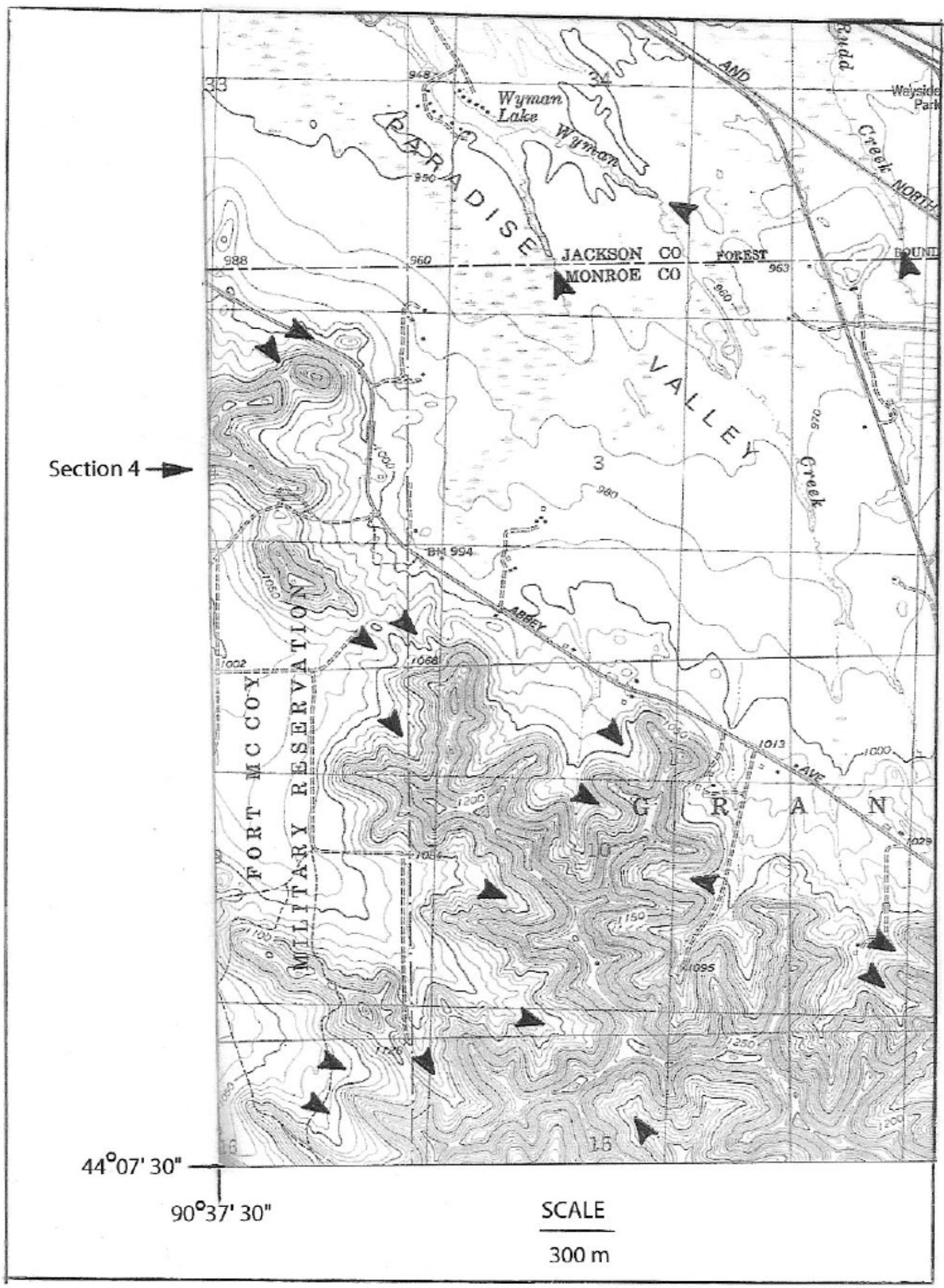

Fig. (14). Map reflecting various types of relic snowmelt-eroded landforms grouped together. Included are NW-SE oriented valleys (indicated by arrows); a pediment of the sandflats (represented by Paradise Valley); a scalloped upland with a sickle-shaped configuration; and at least two semi-isolated rock paha (one is at the end of the word "Reservation" and another one is in Section 4) which are interpreted as transitional paha forms because they are not fully detached from the surrounding uplands. Portion of the Warrens West, WI (1:24,000 scale, 10 -ft. contour interval) quadrangle. North is toward the top. Reproduced through the courtesy of the Wisconsin Geological and Natural History Survey. 
Snow depth and snowbank size in the Driftless Area region during the Pleistocene cold phases would be expected to be greatest in the immediate lee of the ice sheet and decline to the SW away from the margin of the ice sheet. This is what is observed at the margin of the present-day ice sheet edge in Greenland [90]. This is also analagous to eolian sand seas that are deposited immediately in the lee of highlands [91]. The snowbanks at the edge of the Greenland ice sheet [90] are either semi-permanent or permanent because the surrounding snow has already melted away. Erosional activity will occur under permanent snowbanks, which induces the process of cryoplanation [54]. Thus, the greatest erosion (or lopsided erosion) occurred within the Driftless Area because the influx of snow was greatest while cryopedimentation and cryoplanation lessened with more distance downwind toward the SW as paleowinds inevitably lost snow content and velocity with increased distance from the glacial margin. In addition to the erosion from the snowbanks' solifluction and snowmelt sheetwash in the lee of the ice sheet, the snowbanks' solifluction and snowmelt sheetwash would also occur at the base of NE facing scarps. This would be analogous to sand dunes and seas trapped at scarps by wind blowing toward the scarps [91]. Others have noted that slopes facing north erode through nivation faster than slopes facing in other directions $[45,68]$ accelerating the backward retreat of the scarps.

The gradually changing direction of the glacial anticyclonic winds towards the SE [87] (Fig. 1) happens to correlate with a secondary trend of a lessening degree of erosion to the SE. An indication of decreased erosion toward the $\mathrm{SE}$ is the conspicuous narrowing of the Iowan Erosion Surface (that surrounds Iowan paha) to the SE until the erosion surface disappears, as shown in Fig. (1). Also within the Iowan Erosion Surface, the density of Iowan paha greatly increases toward the SE as the planed portion of the Iowan Erosion Surface greatly decreases in area [59]. Farther to the $\mathrm{SE}$ of the Iowan Erosion Surface are the Illinois regional loess paha (Fig. 1) of minimal height with only NW-SE curvilinear lowlands between them, indicating a further decrease in erosion to the SE [20]. The features described above taken together indicate that (paleo)wind and the amount of (paleo)snow decreased towards the SE along with the other SW trend (Fig. 1).

It was argued in previous sections of this paper that the NW-SE wind-deposited snow and its subsequent NW-SE oriented snowmelt with differential frost heave was not only influential to cause the NW-SE trend of the Iowan Erosion Surface but that same process may have also extended the lengths of major NW-SE pre-Illinoian till valleys in northeastern Iowa.

The wind-blown decrease of snow flux to the SW and SE should not have been interrupted seasonally because Knox [5] reports the Driftless Area was probably north of the mean frontal zone that represented the northern boundary of moist air erupted from the Gulf of Mexico during all four seasons of the Pleistocene cold phases. Muhs and Bettis [24] reported that Peoria loess of the Midwest was deposited during dry periods by infrequent northwesterly winds, and reported that those winds were unrelated to winds generated by the glacial anticyclone. Also, the katabatic paleowind that blew from the northeast to the southwest most probably had very little direct effect on the erosion of loess because it would have been anchored to the ground saturated by overland snowmelt flow over the paleopermafrost table. The presence of Pleistocene-age barchans sand dunes in the same region as the Illinois-type loess paha was probably caused by the previously-mentioned northwesterly winds.

\section{A COMPARATIVE PERIGLACIAL AREA}

An area undergoing the slow process of active cryopedimentation is not reported in the literature [45]. However, enormous, largely inactive cryopediments exist but obviously still experience periglacial conditions. These are the cryopediments of the Old Crow Plain in the Yukon Territory [92] and they can be compared to the discussed regions of the Midwest. The Old Crow Plain also contains long stretches of pedimented river valleys such as the Big Fish River, Little Fish River, Rock River and Malcolm River [93]. The Old Crow Plain covers approximately $50,000 \mathrm{~km}^{2}$ [92] and compares in size to the Driftless Area which is $25,900 \mathrm{~km}^{2}$ in area [62]. This size of the Driftless Area may be less because Clayton et al. [94] claimed that the limit of pre-Illinoian glaciation extends farther into the Driftless Area than what was previously reported (Figs. 1, 2). The size of the Paleozoic Plateau is very roughly estimated here as 7500 to $10,000 \mathrm{~km}^{2}$ in size. The location of the Old Crow Plain relative to the late Wisconsinan glacial margin is also similar to the discussed Midwest regions because it is situated just outside the recent glacial limit. Finally, the glacial terrain within the cryopedimented Iowan Erosion Surface is analogous because Hughes [93] mapped some of the pediments of the Old Crow Plain within older glacial terrain.

\section{POSSIBLE GLACIATION OF THE DRIFTLESS AREA AND ITS RELATION TO S.S.S. PROCESSES}

There has long been argument over whether or not the Driftless Area was glaciated in pre-Wisconsinan time. Chamberlain and Salisbury [95] believed that Precambrian highlands just northeast of the Driftless Area in Wisconsin were a formidable obstruction to glacial flow and that the troughs of Lake Superior and Lake Michigan channeled glacial ice around the Driftless Area. Although this may be theoretically plausible, it would also make the Driftless Area a "mega-nunatak" during Pleistocene glaciation of the Midwest. However, such large-scale nunataks are not known elsewhere in the world. Only ambiguity prevails here because a current lack of such large-scale nuntaks does not completely rule out their occurrence during past glacial times. Hobbs [1] provided a fine overview of the controversy concerning whether or not glaciation occurred in the Driftless Area. He argued that as the continental glacier approached the Driftless Area from the west, the permeable and karstic regional bedrock of the Paleozoic Plateau acted as a sieve in dewatering the base of the glacial ice. This dewatering stopped basal sliding and caused the glacier to build a steep glacial front to the west of the Driftless Area [1]. Conversely, Benn and Evans [96] argued for deformation of glacial ice and not basal sliding as the dominant cause of glacial movement. Engelhardt et al. [97] found that glacial motion results from internal creep of glacial ice even when basal sliding rates are low in summer. Shreve [98] theoretically proposed that basal sliding still 
occurs in cold-based glaciers even when subglacial water pressure is nonexistent. His theory was later demonstrated in the field by Eichelmeyer and Wang [99]. These other studies of glacial ice movement put into doubt Hobbs' (1999) contention that the stoppage of basal sliding would have prevented the glacier from entering the Driftless Area.

Connotations surround the fact of the gradual, increasingly diminishment of till that starts at the edge of the Iowan Erosion Surface northeastward toward the border of the Driftless Area [23]. This obvious pattern not only reflects directional erosion but it also prompts an observer to expect a complete absence of till in the Driftless Area.

It should also be noted that the Driftless Area is one of only two places (the second being the Salamanca Reentrant of New York and Pennsylvania) along the southern Laurentide glacial margin where a fringe of older till deposits has not been mapped south of the Wisconsinan limit. That simple observation would imply that the Driftless Area was probably glaciated sometime in the early Pleistocene and the till had since been eroded away. Likewise, on surfaces along the Appalachian plateau in the Salamanca reentrant, erosion (probably periglacial) must have removed all evidence of early and mid-Pleistocene glaciations, leaving an erosional surface, stone-lines, truncated paleosols and periglacial colluvium [100] just like in the study area. The surmise of (paleo)till is corroborated by valleys deeply incised in the plateau surface having thick fills and borehole records indicative of buried materials that are almost certainly till and varves of mid to early Pleistocene age, as estimated by Braun ${ }^{4}$. So the Salamanca reentrant was seemingly glaciated in pre-Wisconsinan times but all evidence was removed except for material buried in the deep valleys that cut the plateau, a topographic situation not available to preserve evidence of early Pleistocene glaciations in the Driftless Area.

The arguments above, taken together, indicate that it remains a reasonable supposition that the Driftless Area was once glaciated in the early Pleistocene. It is here argued that excessive, Pleistocene solifluction and snowmelt sheetwash processes (that originated from iterative, wind-directed snow influx) entirely removed (paleo)till (including paleoerratics) deposits from off the slopes. Trunk valley streams eventually flushed the material out of the area and into the Mississippi River. The removal of even all the erratics is supported by Hughes [68] who reported that the processes of nivation and gelifluction are clearly unfavorable towards the retention of erratics. This also would apply to a subsurface erratic boulder lag because post-depositional, vertical frost heaving during the long stretch of time would have eventually brought this material to the surface, readying it for solifluction transport.

The timing for the deposition of the speculative (paleo)till within the Driftless Area has to be before the deposition of middle Pleistocene, pre-Illinoian loess that retains a normal magnetic polarity and thus a less then 790,000 YBP age. This is because preservation of scarce patches of this loess in the Driftless Area [101] reflects nonglaciation (or no glacial bulldozing) after this time of

\footnotetext{
${ }^{4}$ D. Braun, (personal comm., 2008), Bloomsburg University, Dept. of
} Geography and Geosciences, Bloomsburg, PA 17815 USA. particular loess deposition. Although Jacobs et al. [101] postulated that loess of early Pleistocene time may exist in the Driftless Area, they also reported inferential evidence that all of the early Pleistocene loess could have been removed by major erosional episodes, specifically, periglacial mass wasting when continental glaciers were nearby as reported by Leigh and Knox [102]. Thus, it is not unreasonable to also apply this same periglacial mass wasting in erasing the hypothetical, early Pleistocene (paleo)till from the face of the Driftless Area as well.

\section{CONCLUSIONS}

It is proposed that the landscape in the Driftless Area, and to a lesser degree in the Paleozoic Plateau and the Iowan Erosion Surface has been shaped by Pleistocene solifluction and snowmelt sheetwash processes that have removed large amounts of lithified and unlithified (residual) material. In all three regions, these processes have left extensive relict colluvium and solifluction deposits. Likewise, the regions have similar relict erosional features such as stone-lines and truncated paleosols, and also relict erosional landforms such as the NW-SE-oriented valleys, lithified and unlithified paha, cryoplanation terraces, cryopediments, and cryoplains. These erosional forms collectively indicate that Pleistocene wind-influenced snow was the responsible paleoerosional agent.

The Pleistocene wind-directed snow was effective in its two forms as a blanket and as patterned snowbanks (snow dunes). As a blanket, permafrost active-layer, mass wasting processes (which include solifluction and snowmelt sheetwash) stripped unconsolidated material and reduced bedrock in a uniform manner. Aligned snowbanks or snow dunes carved NW-SE oriented valleys and embryonic landscapes of lithified and unlithified paha. The old age of any paha landscapes resulted from vast erosional surfaces caused by cryoplanation /cryopedimentation. This equates all isolated, lithified and unlithified, paleopermafrost paha to inselbergs that resulted from "non-classical" pedimentation or cryopedimentation. The uplands of the Driftless Area and Paleozoic Plateau exhibit rock paha on plateaus which means the plateaus are now recognized as relict cryoplains.

The Driftless Area experienced the most erosion because it was in the lee of an ancient continental ice front where more snow was being dumped. Erosive stripping was lessened in the SW direction because it was at the far downwind end of the NE paleowind where wind diminishment caused a decreased delivery of snow. Hence, this accounts for the Driftless Area having no till, the Paleozoic Plateau showing an increasing amount of till in the SW direction, and the Iowan Erosion Surface retaining most of its till. As expected, there are less Pleistocene flat landscapes and NW-SE-oriented landscapes southwest of the Iowan Erosion Surface. Physical evidence of the existence of NE paleowinds blowing to the SW, are the ubiquitous, NWSE-oriented snow dune-eroded landforms of all the regions that are transverse to the NE direction.

An additional and similar trend is also conspicuous but to the SE. Distance from the glacial front, however, was not a co-factor. The anticyclonic system that hovered over the ancient continental ice sheet seemed to weaken in this direction and thus, less snow was delivered which caused 
less erosion to occur as exemplified by the reduction of Pleistocene erosional landscapes toward the SE.

The following when added up, indirectly point to preIllinoian continental glaciation in the Driftless Area: the erosional pattern of increased, gradual disappearance of till, as one travels east from the Iowan Erosion Surface through the Paleozoic Plateau and then into the Driftless Area; preIllinoian glacial flowage from the northwest would have progressed unimpeded into the Driftless Area because of its capability of moving over permeable bedrock without the association of subglacial meltwater, and because obstructive highlands are lacking northwest of the Driftless Area; the discounted belief of the Driftless Area as a "mega-nunatak"; the postulation of speculative, early Pleistocene (paleo)loess removal by paleoperiglacial erosion being exactly applied to the like-wise, speculative, early Pleistocene (paleo)till of the Driftless Area; and borehole material indicative of buried till within the parallel region of the Salamanca Reentrant.

The chances of finding till in the Driftless Area are extremely remote because the Driftless Area may be evaluated here as a present-day disconformity in progress. In other words, till may have been deposited and subsequently removed by excessive Pleistocene solifluction and snowmelt sheetwash processes, and Holocene deposits (such as alluvium, lacustrine sediment, etc.) are being deposited today within the Driftless Area.

\section{ACKNOWLEDGEMENTS}

My appreciation is given to James Hedges who provided warm hospitality, and led a personal tour of cryoplanation landforms. A multitude of thanks to Duane Braun who gave extensive, helpful advice on a revision of the manuscript. Suggestions by Norm Catto, Kent Syverson, Richard Marston, Barry Katz and four anonymous reviewers improved the manuscript. Jean Prior, Tom Fenton, Bruce Bown, Dick Anderson, Ed Nater, Roger Peters, James Knox, Michael Mudrey Jr., James Walters, Rhodes Fairbridge and Joe Mason gave beneficial information. Also, there were brief discussions with Craig Kochel, Lee Clayton and John Attig. Bob D'Amico enhanced the graphics.

\section{REFERENCES}

[1] H. Hobbs, "Origin of the Driftless Area by subglacial drainage - a new hypothesis", Geological Society of America, Special Paper vol. 337, pp. 93-102, 1999.

[2] W.I. Anderson, Iowa's Geological Past, Iowa City: University of Iowa Press, 1998.

[3] W.T. Frankie and R.S. Nelson, "Guide to the geology of apple river state park and surrounding area of northeastern Jo Daviess county, Illinois", Illinois State Geological Survey, Field Trip Guidebook 2002B, Champaign, Illinois, 2002.

[4] W. J. Wayne and R. S. Guthrie, "Permafrost and periglacial winds around the Wisconsinan ice margin in the Northern Plains of the U.S.A.", in Proceedings of the 6th International Conference on Permafrost, vol. 1, Beijing, Wushan Guangzhou: South China University of Technology Press, 1993, pp. 694-697.

[5] J. C. Knox, "Quaternary history of the Kickapoo and lower Wisconsin river valleys, Wisconsin", in Quaternary History of the Driftless Area, J. C. Knox, L. Clayton and D. M. Mickelson (field trip committee), Wisconsin Geological and Natural History Survey, 29th Annual Meeting of the Midwest Friends of the Pleistocene, Guidebook vol. 5, pp. $1-65,1982$.

[6] T. A. Frolking, "The genesis and distribution of upland red clays in Wisconsin's Driftless Area", in Quaternary History of the Driftless Area, J.C. Knox, L. Clayton and D.M. Mickelson (field trip committee), Wisconsin Geological and Natural History Survey, 29th Annual
Meeting of the Midwest Friends of Pleistocene, Guidebook vol. 5, pp. 88-97, 1982.

[7] J. C. Prior, Landforms of Iowa, Iowa City: University of Iowa Press, 1991.

[8] R. Wiggers, Geology Underfoot in Illinois, Missoula: Mountain Press Publishing Co., 1997, (pp. 15 and 19).

[9] G. Hallberg, T. E. Fenton, G. A. Miller, A. J. Luteneggar, "The Iowan Erosion Surface, an important lesson and some new wrinkles", in Geology of East-Central Iowa, R. R. Anderson, Ed. Iowa Geological Survey, $42^{\text {nd }}$ Annual tri-State Geological Field Conference, Guidebook, 1978, pp. 2.2-2.94.

[10] H. Hobbs and J. E. Goebel, "Geologic map of Minnesota, Quaternary geology”, Minnesota Geological Survey, map scale 1:500,000, 1982.

[11] R. V. Ruhe, W. P. Dietz, T. E. Fenton and G. F. Hall, 1968, "Iowan drift problem, northeastern Iowa", Iowa Geological Survey, Report of Investigations vol. 7, pp. 40, 1968

[12] B. A. Brown, "Bedrock geology of Wisconsin", West-Central Sheet, Wisconsin Geological and Naural History Survey, Map 88-7, scale 1:250 000, 1 sheet, 1988.

[13] J. H. Mossler, "Bedrock geology of Fillmore County", Minnesota Geological Survey, County Atlas Series C-8, part A, plate 2, map scale 1:100,000, 1995.

[14] S. Judson and G. W. Andrews, "Pattern and form of some valleys in the Driftless Area, Wisconsin", Journal of Geology, vol. 6, pp. 328-336, 1955.

[15] J. C. Prior, Landforms of Iowa, Iowa City: University of Iowa Press, 1991, (p. 32).

[16] L. Clayton and J. W. Attig, "Pleistocene geology of Dane County, Wisconsin". Wisconsin Geological and Natural History Survey, Bulletin vol. 95, pp. 64, 1997.

[17] L. Clayton, J. W. Attig and D.M. Mickelson, "Effects of late Pleistocene permafrost on the landscape of Wisconsin", Boreas, vol. 30, pp. 173-188, 2001.

[18] J. C. Prior, Landforms of Iowa, Iowa City: University of Iowa Press, 1991, (pp. 70, 75 and 96).

[19] M. Iannicelli, "Snow dune erosion and landforms", Northeastern Geol. Environ. Sci., vol. 22, no. 4, pp. 324-335, 2000.

[20] M. Iannicelli, "Devon Island's oriented landforms as an analog to Illinois-type paha", Polar Geography., vol. 27, no. 4, pp. 339-350, 2003

[21] M. D. Mudrey, Jr., B. A. Brown, and J. K. Greenberg, "Bedrock geology map of Wisconsin", Wisconsin Geological and Natural History Survey, State map no.18, scale 1:100,000, 1982.

[22] L. Clayton, "Geology of Juneau County, Wisconsin". Wisconsin Geological and Natural History Survey, Information Circular, vol. 66, pp. 16,1989

[23] P. Horick, "Water resources of northeast Iowa", Iowa Dept. of Natural Resources, Water Atlas no. 8, pp. 133, 1989, (fig. 28).

[24] D. R. Muhs and E. A. Bettis, "Geochemical variations in Peoria loess of western Iowa indicate paleowinds of midcontinental North America during the last glaciation", Quaternary Research, vol. 53, p. 49-61, 2000.

[25] D. M. Mickelson, J. C. Knox, and L. Clayton, 1982, "Glaciation of the Driftless Area: an evaluation of the evidence", in Quaternary history of the Driftless Area, J. C. Knox, L. Clayton and D. M. Mickelson (field trip committee), Wisconsin Geological and Natural History Survey, 29th Annual Meeting of the Midwest Friends of Pleistocene, Guidebook vol. 5, pp.155-169, 1982.

[26] L. Clayton and J.W. Attig, "Geology of Sauk County, Wisconsin", Wisconsin Geological and Natural History Survey, Information Circular vol. 67, pp. 67, 1990.

[27] R.W. Fairbridge and C. Finkl, Jr., "Tropical stone-lines and podzolized sand plains as paleoclimatic indicators for weathered cratons", Quaternary Science Reviews, vol. 3, pp. 41-72, 1984, (pp. 42, 57, and 61-62).

[28] G. Hallberg, T. E. Fenton, G. A. Miller, A. J. Luteneggar, "The Iowan Erosion Surface, an important lesson and some new wrinkles", in Geology of East-Cental Iowa, R. R. Anderson, Ed. Iowa Geological Survey, 42nd Annual Tri-State Geological Field Conference, pp. 18 and 20, Guidebook, pp. 2.2-2.94, 1978.

[29] G. R. Whittecar, "Geomorphic history and Pleistocene stratigraphy of the Petaconic River Valley, Wisconsin and Illinois", Ph.D thesis, University of Wisconsin, Madison, WI USA, 1979.

[30] J. C. Knox, "Quaternary history of the Kickapoo and lower Wisconsin river valleys, Wisconsin", in Quaternary History of the Driftless Area, J. C. Knox, L. Clayton and D. M. Mickelson (field trip committee), 
Wisconsin Geological and Natural History Survey, 29th Annual Meeting of the Midwest Friends of the Pleistocene, Guidebook vol. 5, pp. 1-65, 1982, (p. 15).

[31] L. Clayton, J.W. Attig and D.M. Mickelson, "Effects of late Pleistocene permafrost on the landscape of Wisconsin", Boreas, vol. 30, pp. 173188, 2001, (p. 177).

[32] H. French, The Periglacial Environment, London: Addison Wesley Longman, 1996, (p. 156).

[33] J. C. Frye, H. B. Glass, J. P. Kempton and H. B. Willman, "Glacial tills of northwestern Illinois", Illinois State Geological Survey, Circular vol. 437, p. 45, 1969, (p. 6).

[34] J. A. Mason and J. C. Knox, "Age of colluvium indicates accerlerated late Wisconsinan hillslope erosion in the Upper Mississippi Valley", Geology, vol. 2, pp. 267-270, 1997.

[35] J. C. Walters, "Ice-wedge casts and relict polygonal patterned ground in northeast Iowa, U.S.A.", Permafrost Periglacial, vol. 5, pp. 269-282, 1994.

[36] R. V. Ruhe, W. P. Dietz, T. E. Fenton, and G. F. Hall, 1968, "Iowan drift problem, northeastern Iowa", Iowa Geological Survey, Report of Investigations vol. 7, 1968, p. 40.

[37] W.C. Alden and M.M. Leighton, 1917, "The Iowan drift, a review of the evidences of the Iowan stage of glaciations", Iowa Geological Survey, Annual Report, vol. 26, 1917, pp. 49-212.

[38] G. R. Hallberg, "Wind aligned drainage in loess in Iowa", Proceedings of the Iowa Academy of Science, vol. 86, pp. 4-9, 1979.

[39] W. J. Wayne, "Ice-wedge casts of Wisconsinan age in eastern Nebraska", Permafrost Periglacial, vol. 2, pp. 211-233, 1991.

[40] J. C. Prior, Landforms of Iowa. Iowa City: University of Iowa Press, 1991, (p. 78).

[41] W. I. Anderson, Iowa's Geological Past. Iowa City: University of Iowa press, 1998, (p. 337).

[42] J. Budel, Climatic Geomorphology, New Jersey: Princeton University Press, 1982, (p. 299).

[43] B. Marsh, "Wind-transverse corrugations in Pleistocene periglacial landscapes of Pennsylvania", Quaternary Research, vol. 49, pp. 149156, 1998.

[44] W. J. McGee, "The Pleistocene history of northeastern Iowa", U.S Geological Survey, Eleventh Annual Report, pp. 189-577, 1891, (pp. 363-365).

[45] H. French, The Periglacial Environment. London: Addison Wesley Longman, 1996.

[46] T. Sorensen, 1935, "Ground form and plant cover in North East Greenland" (reprinted in 1994), in Cold Climate Landforms, D. J. A. Evans, Ed. (translated), Chichester, New York and other locations: J. Wiley and Sons, pp. 135-175, 1935, (p. 146).

[47] J. C. Prior, D. D. Smith, D. M. Roosa, P. Christiansen, and L. Eilers, "Natural history of the Cedar and Wapsipinicon River basins of the Iowan Erosion Surface", Iowa Natural History Association, Waverly, Guidebook vol. 4, pp. 22, 1986, (p. 3).

[48] P. J. Horick, "Water resources of northeast Iowa", Iowa Dept. of Natural Resources, Geological Survey Bureau, Water Atlas no. 8, pp. 133, 1989, (p. 49).

[49] L. Clayton and J.W. Attig, "Pleistocene geology of Dane County, Wisconsin", Wisconsin Geological and Natural History Survey, Bulletin vol. 95, 1997, p. 64 (pp. 21-22).

[50] L. Clayton, J.W. Attig and D.M. Mickelson, "Effects of late Pleistocene permafrost on the landscape of Wisconsin", Boreas, vol. 30, pp. 173188, 2001, (p. 178).

[51] R. Flemal, I.E. Odom and R.G. Vail, "Stratigraphy and origin of the paha topography of northwestern Illinois", Quaternary Research, vol. 2, pp. 232-243, 1972

[52] J. A. Mason, E. A. Nater, C. W. Zanner, and J. C. Bell, "A model of topographic effects on the distribution of loess", Geomorphology, vol. 28, pp. 223-236, 1999, (p. 233)

[53] A. Busacca, "Dust aerosols, loess soils, and global change", A Field Tour Guide, Dept. Of Crop and Soil Sciences, Washington St. University, Pullman, Washington, 1998, (Stop 1, Day 1).

[54] K. Priesnitz, "Cryoplanation", in Advances in Periglacial Geomorphology, M. J. Clark, Ed. Chichester, New York and other locations: J. Wiley and Sons, 1988, pp. 49-67.

[55] S. A. Grosso and A. E. Corte, "Cryoplanation surfaces in the Central Andes at latitude $35^{\circ}$ S", Permafrost Periglacial, vol. 2, pp. 49-58, 1991.

[56] H. French, The Periglacial Environment, London: Addison Wesley Longman, 1996, (p. 192).
[57] G.M. Clark and J. Hedges, "Origin of certain high elevation local broad uplands in the central Appalachians, south of the USA glacial bordera paleoperiglacial hypothesis" in Periglacial Geomorpholgy, J. C. Dixon and A. D. Abrahams, Eds. Chichester, New York and many other locations: J. Wiley and Sons, 1992, pp. 31-62.

[58] G. R. Hallberg, "Pleistocene stratigraphy in east-central Iowa", Iowa Geological Survey, Technical Information Series vol. 10, pp. 168, 1980, (fig. 19).

[59] W. H. Sholtes, "Properties and classification of the paha loess-derived soils in northeastern Iowa", Iowa St. College Journal of Science, vol. 10, pp. 163-209, 1955.

[60] L. Clayton and F.W. Madison, "Pleistocene history of the Black River Falls Area", in Three Billion Years of Geology, B.A. Brown, Ed. Wisconsin Geological and Natural History Survey, 47th Annual TriState Geological Field Conference, Guidebook vol. 9, pp. 10-13, 1983.

[61] R. D. Reger and T. L. Pewe, "Cryoplanation terraces: indicators of a permafrost Environment", Quat. Res., vol. 6, pp. 99-109, 1976.

[62] R. F. Black, "Geology of Ice Age National Scientific Reserve of Wisconsin", National Park Service Scientific Monograph Series, no. 2, Denver, pp. 234, 1974.

[63] D. Briggs, P. Smithson, K. Addison and K. Atkinson, Fundamentals of the Physical Environment. London and other locations: Routledge, 1997, (p. 456).

[64] G.M. Clark and J. Hedges, "Origin of certain high elevation local broad uplands in the central Appalachians, south of the USA glacial bordera paleoperiglacial hypothesis" in Periglacial Geomorpholgy, J. C. Dixon and A. D. Abrahams, Eds. Chichester, New York and many other locations: J. Wiley and Sons, pp. 31-62, 1992, ( pp. 40 and 53).

[65] H. French, The Periglacial Environment, London: Addison Wesley Longman, 1996, (p. 178).

[66] L. Clayton and J.W. Attig, "Pleistocene geology of Dane County, Wisconsin", Wisconsin Geological and Natural History Survey, Bulletin vol. 95, 1997, p. 64 (fig. 39).

[67] R. D. Reger and T. L. Pewe, "Cryoplanation terraces: indicators of a permafrost Environment", Quaternary Research, vol. 6, pp. 99-109, 1976, (pp. 102-103).

[68] O. L. Hughes, "Surficial geology and geomorpholgy, Aishihik Lake, Yukon Territory", Geological Survey of Canada, Paper 87-29, pp. 23 , 1990.

[69] S. G. Boch, and I.I. Krasnov, "On altiplanation terraces and ancient surfaces of levelling in the Urals and associated problems" (reprinted in 1994), in Cold Climate Landforms, D.J.A. Evans, Ed. (translated), Chichester, New York and other locations: J. Wiley and Sons, 1943, pp. 177-186.

[70] L. Clayton and J.W. Attig, "Pleistocene geology of Dane County, Wisconsin", Wisconsin Geological and Natural History Survey, Bulletin vol. 95, pp. 64, 1997, (p. 35).

[71] L. Clayton and J.W. Attig, "Geology of Sauk County, Wisconsin", Wisconsin Geological and Natural History Survey, Information Circular vol. 67, pp. 67, 1990, (p. 30).

[72] A. C. Runkel, "Bedrock geology of Houston County, Minnesota", Minnesota Geological Survey, Open-File Report 96 - 4, map and technical report, scale 1:100,000, 1994.

[73] A. C. Runkel, "Bedrock geology of Houston County, Minnesota", Minnesota Geological Survey, Open-File Report 96-4, map and technical report, scale 1:100,000,1994, (plates 1 and 2).

[74] D. S. Leigh and J. C. Knox, "Loess of the Upper Mississippi driftless Area", Quaternary Research, vol. 42, pp. 30-40, 1994, (p. 37).

[75] R. Wiggers, Geology Underfoot in Illinois, Missoula: Mountain Press Publishing Co., 1997, (pp. 15-16).

[76] W. T. Frankie and R. S. Nelson, 2002, "Guide to the geology of Apple River State Park and surrounding area of northeastern Jo Daviess county, Illinois", Illinois State Geological Survey, Field Trip Guidebook 2002B, Champaign, Illinois, 2002, (p. 15).

[77] J. H. Mossler, and H. C. Hobbs, "Depth to bedrock and bedrock topography of Fillmore County, Minnesota", Minnesota Geological Survey, County Atlas Series C-8, part A, plate 4, map scale 1:100 000, 1995.

[78] H. C. Hobbs, "Surficial geology of Fillmore County", Minnesota Geological Survey, County Atlas Series C-8, part A, plate 3, map scale 1:100 000, 1995.

[79] T. Czudek, "Pleistocene periglacial structures and landforms in western Czechoslovakia". Permafrost Periglacial, vol. 4, pp. 65-75, 1993, (pp. 73 and 74).

[80] T. J. Evans, "Geology of LaCrosse County, Wisconsin". Wisconsin Geological and Natural History Survey, Bulletin vol. 101, 2003, p. 31. 
[81] G. R. Hallberg, T. E. Fenton, G. A. Miller, and A. J. Luteneggar, "The Iowan Erosion Surface, an important lesson and some new wrinkles", in Geology of East-Central Iowa, R. R. Anderson, Ed. Iowa Geological Survey, $42^{\text {nd }}$ Annual Tri-State Geological Field Conference, Guidebook, pp. 2.2-2.94, 1978, (plate 2.1 and figure 5).

[82] J. Hedges and G. W. Darland, "The Scotch Grove strath in Maquoketa River valley, Iowa", Iowa Academy of Science Proceedings, vol. 70, pp. 295-306, 1963, (fig. 2).

[83] E. A. Bettis, "Quaternary geology of Backbone State Park", in Natural History of Backbone State Park, Delaware County, Iowa, R. R. Anderson, Ed., Geological Society of Iowa, Guidebook vol. 61, 1995, pp. $19-21$.

[84] G. A. Ludvigson, E. A. Bettis, and C. M. Hudak, "Quaternary drainage evolution of the Maquoketa River valley", Geological Society of Iowa, Guidebook vol. 56, pp. 45, 1992.

[85] P. D. Jungerius, "Age and origin of the Cypress Hills plateau surface in Alberta", Geographic Bulletin, vol. 8, pp. 307-318, 1966.

[86] P. D. Jungerius, "The influence of Pleistocene climatic changes on the development of the polygenetic pediments in the Cypress Hills area", Geographic Bulletin, vol. 9, pp. 218-231, 1967.

[87] COHMAP Members, "Climatic changes of the last 18,000 years: observations and model Simulations", Science, vol. 241, pp. 1043-1052, 1988.

[88] J. C. Prior, Landforms of Iowa, Iowa City: University of Iowa Press, 1991, (pp. 93 and 96).

[89] W. I. Anderson, Iowa's Geological Past, Iowa City: University of Iowa press, 1998, (fig. 10.22).

[90] R. R. Compton, Interpreting the Earth, New York and other locations: Harcourt Brace Jovanovich, 1977, (fig. 7.8).

[91] D. S. G. Thomas, "Sand seas and aeolian bedforms", in Arid Zone Geomorphology, D. S. G. Thomas, Ed. Chichester, New York and many other locations: J. Wiley and Sons, pp. 373-412, 1998, (fig. 17.4).

[92] H. French, 1987, "Periglacial processes and landforms in the Western Canadian Arctic", in Periglacial Processes and Landforms in Britain and Ireland, J. Boardman, Ed. Cambridge, New York and many other locations: J. Wiley and Sons, 1987, pp. 27-43.

[93] O. L. Hughes, "Surficial geology of northern Yukon territory and northwestern District of Mackenzie, Northwest Territories", Geological Survey of Canada, Paper 69-36, pp. 11, 1972.
[94] L. Clayton, J.W. Attig, D.M. Mickelson and M.D. Johnson, "Glaciation of Wisconsin". Wisconsin Geological and Natural History Survey, Educational Series vol. 36, p. 4, 1992.

[95] T.C. Chamberlain and R.D. Salisbury, "On the Driftless Area of the Upper Mississippi Valley", U.S. Geological Survey, $6^{\text {th }}$ Annual Report, 1885, pp. 199-322.

[96] D. I. Benn and D. J. A. Evans, Glaciers and Glaciation, London: Arnold Publishers, 1998.

[97] H. F. Engelhardt, W. D. Harrison, and B. Kamb, "Basal sliding and conditions at the glacier bed as revealed by borehole photography", Journal of Glaciology, vol. 20, pp. 469-508, 1978.

[98] R. L. Shreve, "Glacier sliding at subfreezing temperatures", Journal of Glaciology, vol. 30, pp. 341-347, 1984.

[99] K. Eichelmeyer and Z. Wang, "Direct observation of basal sliding and deformation of basal drift at subfreezing temperatures", Journal of Glaciology, vol. 33, pp. 83-98, 1987.

[100] K. E. Snyder and R. B. Bryant, 1992, "Late Pleistocene surficial stratigraphy and landscape development in the Salamanca Reentrant, southwestern New York", Geological Society of America Bulletin, vol. 104, pp. 242-251, 1992.

[101] P. M. Jacobs, J.C. Knox, and J.A. Mason, "Preservation and recognition of middle and early Pleistocene loess in the Driftless Area, Wisconsin", Quaternary Research, vol. 47, pp. 147-154, 1997.

[102] D. S. Leigh and J. C. Knox, "Loess of the Upper Mississippi driftless Area" Quaternary Research, vol. 42, pp. 30-40, 1994, (p. 36).

[103] F. T. Thwaites, "Wisconsinan glacial deposits", Wisconsin Geological and Natural History Survey, State map no.19, scale 1:1,500,000, 1960.

[104] R. F. Sloan and G. S. Austin, "Geologic map of Minnesota, St. Paul sheet", Minnesota Geological Survey, map scale 1: 250,000, 1966.

[105] G. L. Laberge, Geology of the Lake Superior Region, Oshkosh, Wisconsin: Penokeon Press, 1994.

[106] H. French, The Periglacial Environment. London: Addison Wesley Longman, 1996 (fig. 15.12).

[107] M. E. Long, "Mars on Earth", National Geographic, vol. 196, pp. 34 $51,1999$.

[108] M. J. Clark, "Periglacial Hydrology", in Advances in Periglacial Geomorphology, M. J. Clark, Ed. Chichester, New York and many other locations: J. Wiley and Sons, 1988, pp. 415-462.

[109] A. Jahn, "Periglacial microrelief in the Tatras and on Babia Gora", Biul. Peryglac., vol. 6, pp. 227-249, 1958.

(C) Michael Iannicelli; Licensee Bentham Open.

This is an open access article licensed under the terms of the Creative Commons Attribution Non-Commercial License (http: //creativecommons.org/licenses/by-nc/ $3.0 /$ ) which permits unrestricted, non-commercial use, distribution and reproduction in any medium, provided the work is properly cited 